\title{
Enantiocomplementary Chiral Polyhydroxyenoate: Chemo-enzymatic Synthesis and Helical Structure Control
}

\author{
Yu Zhang, ${ }^{\dagger}$ Bo Xia, ${ }^{\ddagger}$ Yujing Hu, ${ }^{\dagger}$ Qiaoyan Zhu, ${ }^{\dagger}$ Xianfu Lin, ${ }^{\dagger, *}$ Qi Wu ${ }^{\dagger, *}$ \\ † Department of Chemistry, Zhejiang University, Hangzhou 310027, PR China \\ ¥ Jiyang College of Zhejiang A\&F University, Zhuji 311800, PR China
}

\section{Table of content}

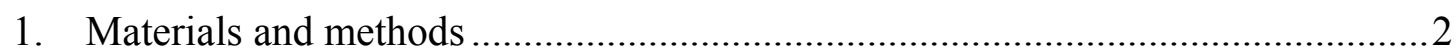

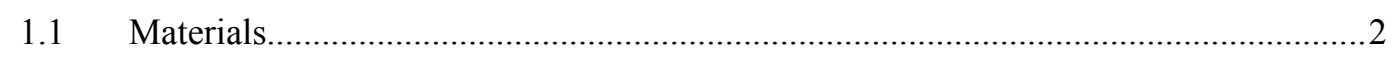

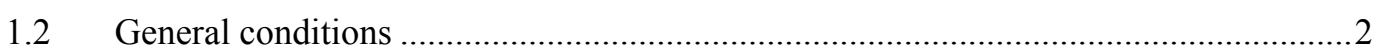

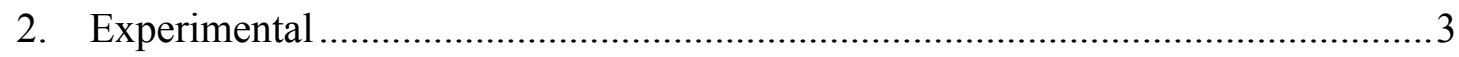

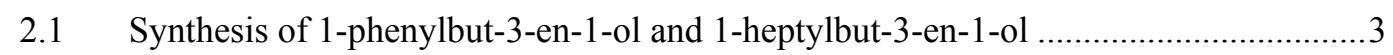

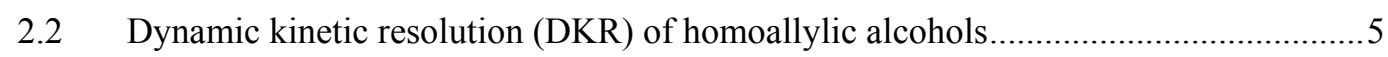

2.3 Synthesis of ethyl 5-hydroxy-5-substituted-2-enoate................................................6

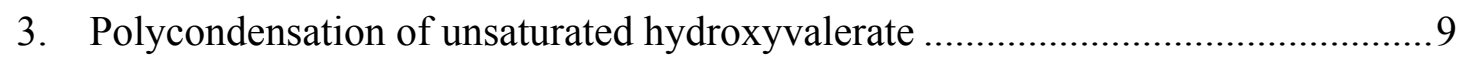

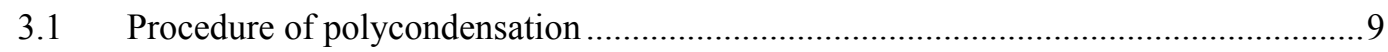

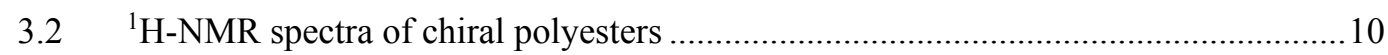

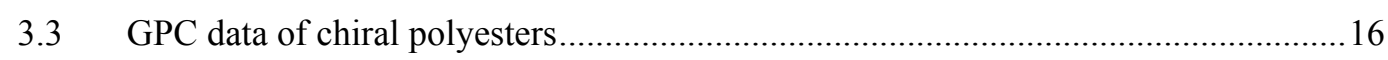

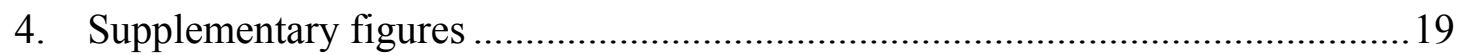

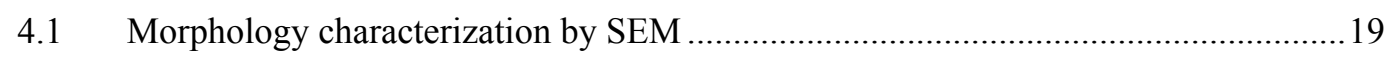

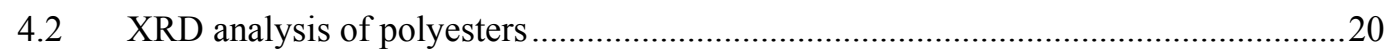

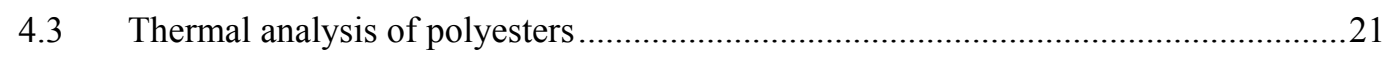

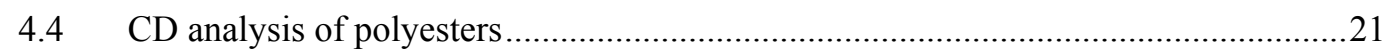

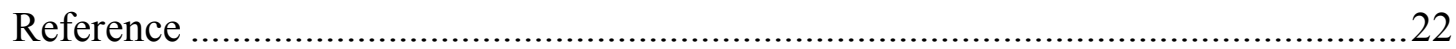




\section{Materials and methods}

\subsection{Materials}

Immobilized Lipase B from Candida antarctica (Novozym 435, CALB) was purchased from Sigma-Aldrich. The CALB mutant (W104V/A281L/A282K) with reversed stereoselectivity was prepared according to the previous procedure reported by our group ${ }^{1-2}$. Benzaldehyde, 3-bromopropene, n-octaldehyde and titanium tetrabutoxide $\left(\mathrm{Ti}(\mathrm{OBu})_{4}\right)$ were purchased from Energy Chemical, Grubbs $2^{\text {nd }}$ catalyst was purchased from Coach Chemical, others were purchased from were purchased from Sinopharm Chemical Reagent Co. Ltd. (Shanghai, China). All the reagents were of analytical grade and used without further purification.

\subsection{General conditions}

Nuclear Magnetic Resonance (NMR) ${ }^{1} \mathrm{H}$ NMR and ${ }^{13} \mathrm{C}$ NMR spectra were recorded with tetramethylsilane (TMS) as the internal standard using a Bruker AMX-400 MHz spectrometer (Rheinstetten, Germany) using $\mathrm{CDCl}_{3}$ as solvents. ${ }^{1} \mathrm{H}$ and ${ }^{13} \mathrm{C}$ spectra were recorded using the standard pulse sequence provided by Bruker. The samples were analyzed at $25{ }^{\circ} \mathrm{C}$. TMS (ppm: 0) was used as the internal standard for NMR analysis.

Thermal Analysis Differential thermal analysis was carried out with a DSCQ1000 TA Instrument, with the calorimeter under nitrogen $(30 \mathrm{~mL} / \mathrm{min})$ connected to a cryostat from the same manufacturer, standard experiments were conducted with a heating rate of $10^{\circ} \mathrm{C} / \mathrm{min}$ from $0^{\circ} \mathrm{C}$ to $120^{\circ} \mathrm{C}$. TG experiments were prepared in crimped aluminum pans and standard experiments were conducted with a heating rate of $20^{\circ} \mathrm{C} / \mathrm{min}$ from R.T. to $600^{\circ} \mathrm{C}$.

Gel Permeation Chromatography (GPC) Molecular weights of polyesters were measured by GPC with a system equipped with a refractive-index detector (Waters 2414) and Waters Styragel GPC columns (Massachusetts, USA). The GPC columns were standardized with narrow-dispersity polystyrene in molecular weight ranging from $6 \times 10^{5}$ to 500 . The mobile phase was THF at a flow rate of $1.0 \mathrm{~mL} / \mathrm{min}$.

Scanning Electron Microscopy (SEM) Samples were prepared by loading $4 \mu \mathrm{L}$ of the polymers solution onto a silicon wafer. After drying overnight, the samples were coated with $\mathrm{Cr}$ for conductance and viewed and analyzed by scanning electron microscopy on Hitachi SU-8010 with an accelerating voltage of $3.0 \mathrm{kV}$.

Circular Dichroism (CD) CD spectra were recorded on a JASCO J-815 spectrometer. The light path length of the quartz cell used was $10 \mathrm{~mm}$. The concentration was about $1.0 \times 10^{-5} \mathrm{~mol} / \mathrm{L}$, and the solvent is acetonitrile.

X-ray Diffraction (XRD): XRD patterns were recorded with a PANalytical X'Pert PRO powder diffractometer using $\mathrm{Cu} \mathrm{K} \alpha$ radiation $(\lambda=0.1541 \mathrm{~nm})$. The working voltage was $40 \mathrm{kV}$ and the working current was $40 \mathrm{~mA}$. The patterns were collected with a $2 \theta$ range from $5^{\circ}$ to $40^{\circ}$ at a step of $0.0501^{\circ}$. 


\section{Experimental}

\subsection{Synthesis of 1-phenylbut-3-en-1-ol and 1-heptylbut-3-en-1-ol}

1-Phenylbut-3-en-1-ol: to a vigorously stirred emulsion of saturated aqueous $\mathrm{NH}_{4} \mathrm{Cl}(45 \mathrm{~mL})$ and THF $(9 \mathrm{~mL})$ was added $\mathrm{Zn}(6.00 \mathrm{~g}, 91.8 \mathrm{mmol})$, benzaldehyde $(5.3 \mathrm{~g}, 50.0 \mathrm{mmol})$ and 3-bromopropene $(6.65 \mathrm{~g}, 55.0 \mathrm{mmol})$. The mixture was stirred for $1 \mathrm{~h}$ at room temperature and extracted with ethyl acetate three times. The combined organic extracts were dried over $\mathrm{MgSO}_{4}$, filtered and concentrated in vacuum rotatory evaporator. The residue was purified by column chromatography on silica (petroleum ether/ethyl acetate $=10 / 1$ ) to get $6.5 \mathrm{~g}$ pure $\mathbf{1 a}$. The isolated yield of 1a is $86 \%$. Spectral data was in accordance with the literature ${ }^{3}$.

1-phenylbut-3-en-1-ol (1a): ${ }^{1} \mathrm{H}-\mathrm{NMR}\left(400 \mathrm{MHz}, \mathrm{CDCl}_{3}\right) \delta$ : $7.39-7.26(\mathrm{~m}, 5 \mathrm{H}), 5.91-5.71(\mathrm{~m}$, 1H), $5.21-5.09$ (m, 2H), 4.74 (dd, $J=7.7,5.2 \mathrm{~Hz}, 1 \mathrm{H}), 2.59-2.44(\mathrm{~m}, 2 \mathrm{H})$.

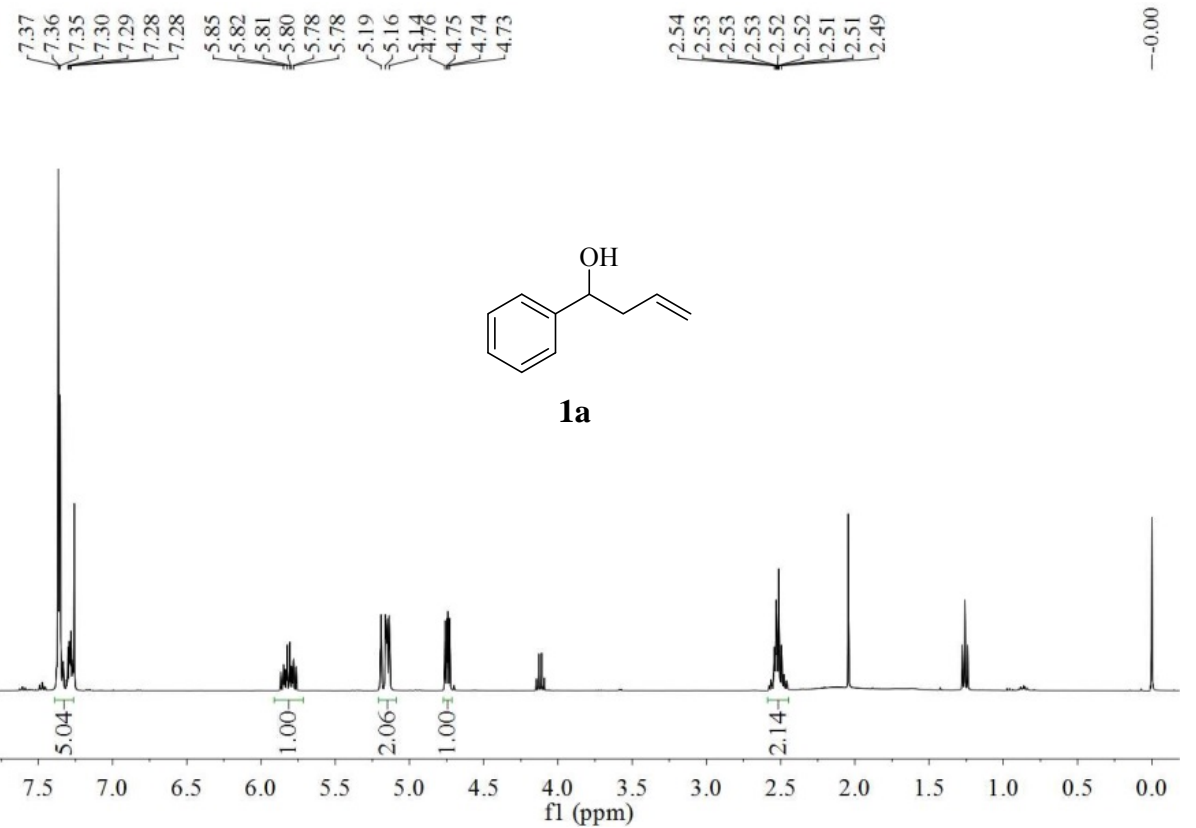


A similar procedure was applied for the synthesis of 1-heptylbut-3-en-1-ol (1b) with octanal instead of benzaldehyde. The isolated yield of $\mathbf{1 b}$ is $88 \%$. Spectral data was in accordance with the literature ${ }^{3}$.

1-heptylbut-3-en-1-ol (1b): ${ }^{1} \mathrm{H}$ NMR (400 MHz, $\mathrm{CDCl}_{3}$, ppm) $\delta: 5.92-5.75(\mathrm{~m}, 1 \mathrm{H}), 5.14$ (dd, $J$ $=13.7,1.9 \mathrm{~Hz}, 2 \mathrm{H}), 3.72-3.58(\mathrm{~m}, 1 \mathrm{H}), 2.38-2.07(\mathrm{~m}, 2 \mathrm{H}), 1.46(\mathrm{dd}, J=7.9,4.2 \mathrm{~Hz}, 3 \mathrm{H}), 1.37$ $-1.20(\mathrm{~m}, 10 \mathrm{H}), 0.88(\mathrm{t}, J=6.9 \mathrm{~Hz}, 3 \mathrm{H})$.

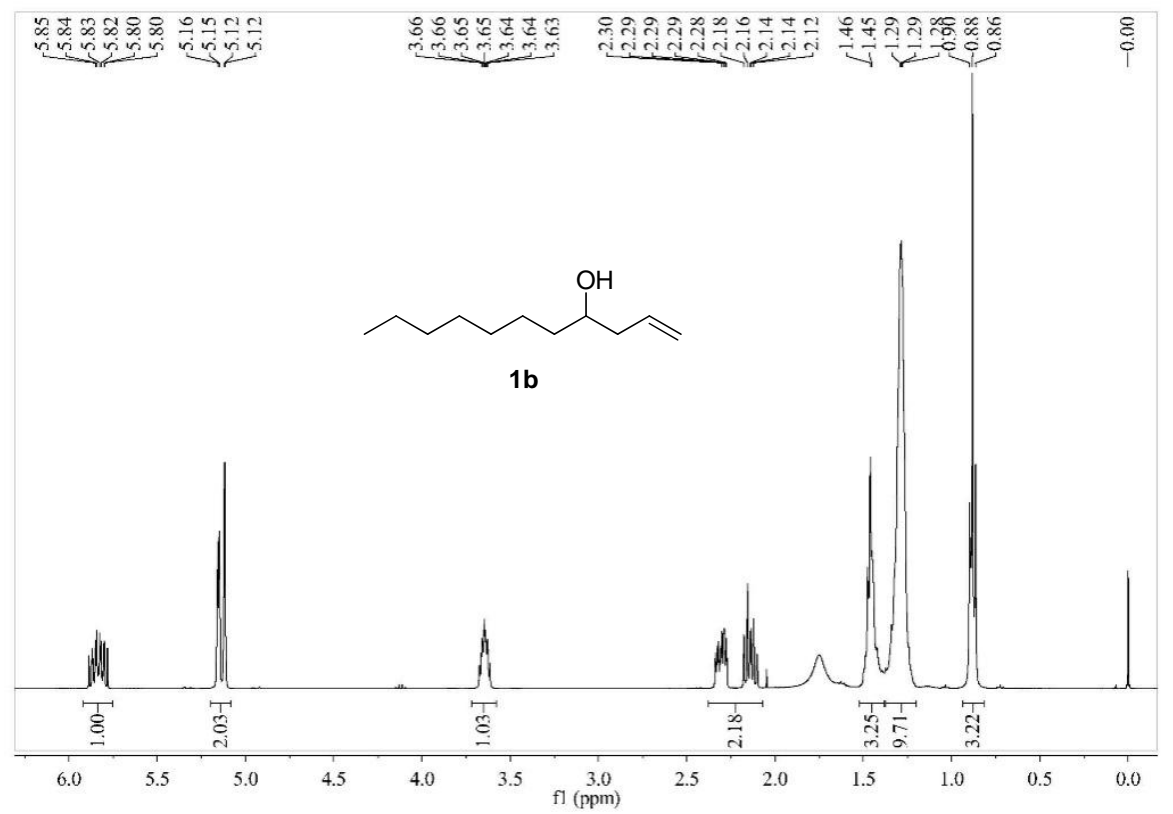




\subsection{Dynamic kinetic resolution (DKR) of homoallylic alcohols}

All DKR reactions were run on $5 \mathrm{mmol}$ scale of the homoallylic alcohol. To a dried Schlenck tube, Shvo's catalyst $(5.0 \mathrm{~mol} \%), \mathrm{Na}_{2} \mathrm{CO}_{3}(5 \mathrm{mmol})$ and lipase $(10 \mathrm{wt} \%)$ were added. The tube was back-flushed with nitrogen, and dry toluene $(10 \mathrm{~mL})$ was added with needle syringe. The reaction was heated to $50^{\circ} \mathrm{C}$ and stirred for 5.0 minutes, and then rac-homoallylic alcohol (1a or $\mathbf{1 b}, 5$ mmol, dissolved in $10 \mathrm{~mL}$ dry toluene) was added. After another 5.0 minutes, vinyl acetate (15 mmol, 3.0 equiv, dissolved in $10 \mathrm{~mL}$ toluene) was added. The reaction was kept at $50{ }^{\circ} \mathrm{C}$ and stirred for $24 \mathrm{~h}$ before detection.

The solvent was removed by reduced pressure distillation. The residue was further purified by silica gel column (petroleum ether/ethyl acetate $=10 / 1$ ) to give enantiopure homoallylic acetate (2a or $\mathbf{2 b}$ ). The product was then dissolved in $10 \mathrm{~mL}$ methanol, and $\mathrm{K}_{2} \mathrm{CO}_{3}$ (2 equiv, dissolved in 40 $\mathrm{mL} \mathrm{H}_{2} \mathrm{O}$ ) was added. After stirring 12 hours at $37^{\circ} \mathrm{C}$, the methanol was evaporated under vacuum and the reaction was extracted with $20 \mathrm{~mL}$ EtOAc for three times, and the combined organic phase was dried over anhydrous $\mathrm{MgSO}_{4}$, filtered and concentrated in vacuo to give pure $(R)$ or $(S)-\mathbf{1 a} / \mathbf{b}$.

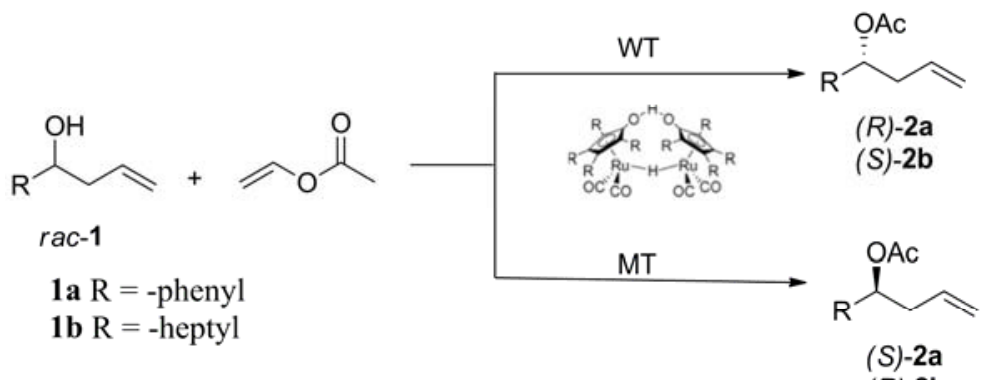

(R)-2b

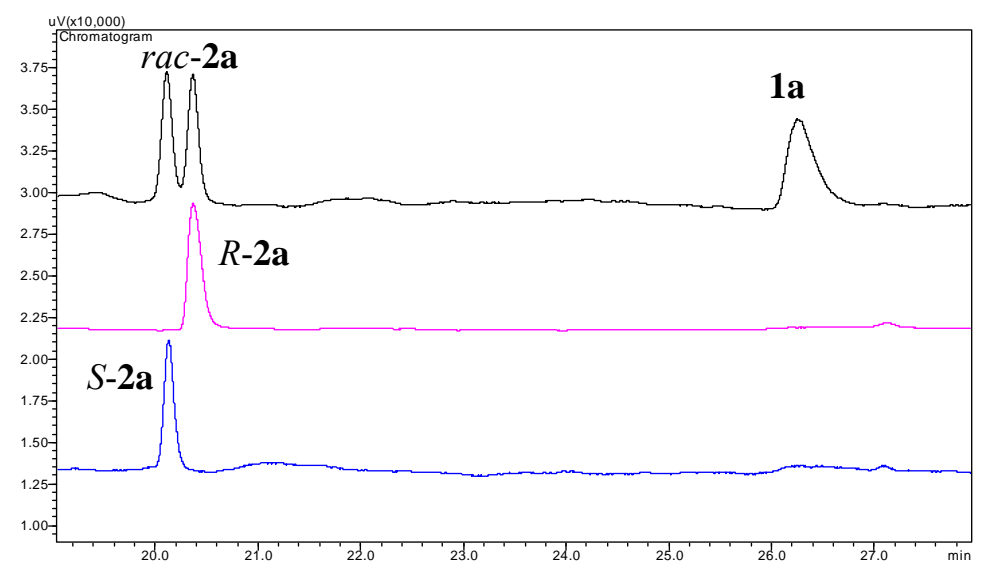

Figure S1. Chiral GC analysis of enzymatic esterification DKR of 1a. Black line: reference sample of rac-2a and $\mathrm{rac}-1 \mathbf{a}\left(T_{S-2 \mathbf{a}}=20.2 \mathrm{~min}, T_{R-2 \mathbf{a}}=20.4 \mathrm{~min}, T_{\text {rac-1a }}=26.4 \mathrm{~min}\right)$; Red line: DKR result catalyzed by WT-CALB; Blue line: DKR result catalyzed by MT-CALB. GC conditions: Agilent $\mathrm{CP}$-chirasil-Dex $\mathrm{CB}$, Temperature conditions: initial temperature $80^{\circ} \mathrm{C}, 2.0^{\circ} \mathrm{C}$ $/ \mathrm{min}$ to $140{ }^{\circ} \mathrm{C}$, then $40^{\circ} \mathrm{C} / \mathrm{min}$ to $200^{\circ} \mathrm{C}$, holding $1.0 \mathrm{~min}$. 


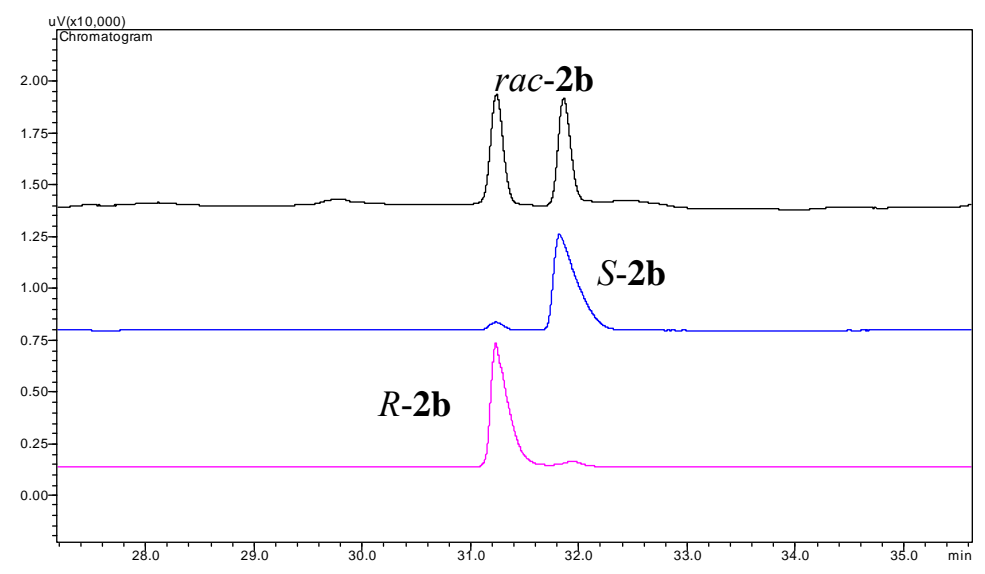

Figure S2. Chiral GC analysis of enzymatic esterification DKR of 1b. Black line: reference sample of rac-2b $\left(T_{R-2 \mathbf{b}}=31.2 \mathrm{~min}, T_{S-2 \mathbf{b}}=31.8 \mathrm{~min}\right)$; Blue line: DKR result catalyzed by WT-CALB; Red line: DKR result catalyzed by MT-CALB. GC conditions: Agilent CP-chirasil-Dex CB, Temperature conditions: initial temperature $60{ }^{\circ} \mathrm{C}, 2.0^{\circ} \mathrm{C} / \mathrm{min}$ to $140{ }^{\circ} \mathrm{C}$, then $40{ }^{\circ} \mathrm{C} / \mathrm{min}$ to $200{ }^{\circ} \mathrm{C}$, holding $1.0 \mathrm{~min}$.

\subsection{Synthesis of ethyl 5-hydroxy-5-substituted-2-enoate}

A typical procedure for unsaturated hydroxyvalerate monomers was described. For ethyl 5-hydroxy-5-phenylpent-2-enoate (3a), to a solution of $1 \mathbf{a}(1.48 \mathrm{~g}, 10 \mathrm{mmol})$ and ethyl acrylate (3 $\mathrm{g}, 30 \mathrm{mmol})$ in DCM $(50 \mathrm{~mL})$, a solution of Grubbs $2^{\text {nd }}$ catalyst $(0.15 \mathrm{~g}, 10 \% \mathrm{wt})$ in $20 \mathrm{~mL}$ DCM was added dropwise at $0{ }^{\circ} \mathrm{C}$ under a nitrogen atmosphere. The reaction mixture was refluxed for 12 hours under a nitrogen atmosphere. The solvent was removed by reduced pressure distillation. The residue was further purified by silica gel column (petroleum ether/ethyl acetate $=6 / 1$ ) to get $1.85 \mathrm{~g}$ pure 3a. Yield $=84 \%$. Spectral data was in accordance with the literature ${ }^{4}$. 
Ethyl 5-hydroxy-5-phenylpent-2-enoate (3a): ${ }^{1} \mathrm{H}-\mathrm{NMR}\left(400 \mathrm{MHz}, \mathrm{CDCl}_{3}, \mathrm{ppm}\right) \delta: 7.42-7.27$ (m, 5H), 6.96 (dt, $J=15.6,7.3 \mathrm{~Hz}, 1 \mathrm{H}), 5.90$ (dt, $J=15.7,1.4 \mathrm{~Hz}, 1 \mathrm{H}), 4.83(\mathrm{dd}, J=7.7,5.2 \mathrm{~Hz}$, $1 \mathrm{H}), 4.17$ (q, $J=7.1 \mathrm{~Hz}, 2 \mathrm{H}), 2.74-2.54(\mathrm{~m}, 2 \mathrm{H}), 1.27$ (t, $J=7.1 \mathrm{~Hz}, 3 \mathrm{H}) ;{ }^{13} \mathrm{C}$ NMR $(101 \mathrm{MHz}$, $\left.\mathrm{CDCl}_{3}, \mathrm{ppm}\right) \delta 166.35,144.69,143.47,128.64,127.95,126.06,125.74,124.06,121.72,73.11$, $60.34,41.88,14.25$.
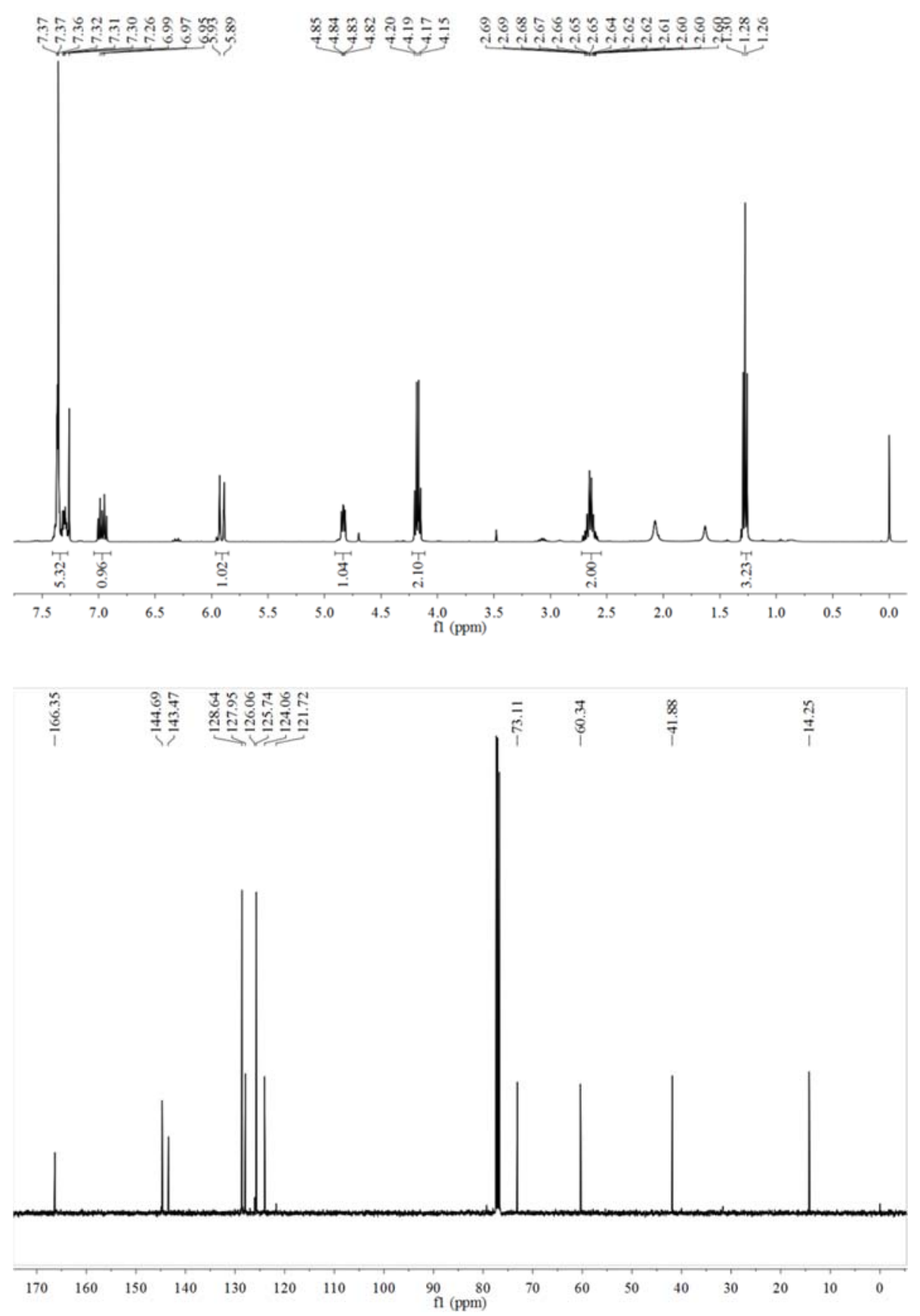
A similar procedure was applied for the synthesis of ethyl 5-hydroxydodec-2-enoate with $\mathbf{1 b}$ instead of 1a. Yield $=80 \%$. Spectral data was in accordance with the literature ${ }^{5}$.

Methyl 5-hydroxydodec-2-enoate (3b): ${ }^{1} \mathrm{H}$ NMR (400 MHz, $\mathrm{CDCl}_{3}$, ppm) $\delta 7.04-6.90$ (m, 1H), $5.91(\mathrm{dt}, J=15.6,1.4 \mathrm{~Hz}, 1 \mathrm{H}), 4.19(\mathrm{q}, J=7.1 \mathrm{~Hz}, 2 \mathrm{H}), 3.76(\mathrm{dt}, J=12.1,6.2 \mathrm{~Hz}, 1 \mathrm{H}), 2.47-$ $2.24(\mathrm{~m}, 2 \mathrm{H}), 1.52-1.43(\mathrm{~m}, 3 \mathrm{H}), 1.29(\mathrm{t}, J=7.1 \mathrm{~Hz}, 13 \mathrm{H}), 0.88(\mathrm{t}, J=6.9 \mathrm{~Hz}, 3 \mathrm{H}) ;{ }^{13} \mathrm{C} \mathrm{NMR}$ $\left(101 \mathrm{MHz}, \mathrm{CDCl}_{3}\right.$, ppm) $\delta 166.36,145.20,123.91,70.61,60.32,40.18,37.16,31.80,29.51,29.25$, $25.60,22.65,14.27,14.10$.
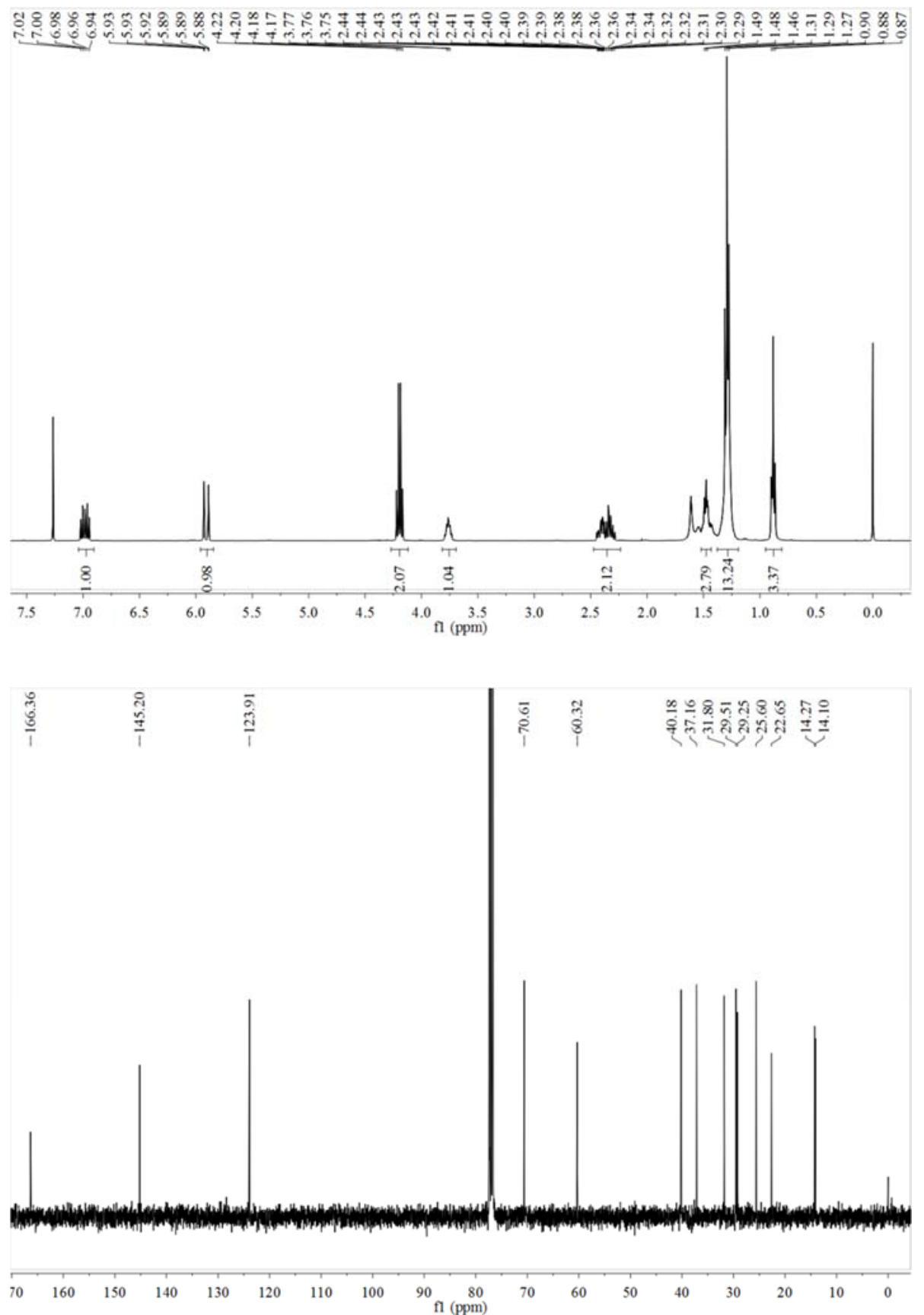


\section{Polycondensation of unsaturated hydroxyvalerate}

\subsection{Procedure of polycondensation}

A typical polycondensation procedure was applied for the $\omega$-substituted hydroxyvalerate. The monomer (3a) (220 mg, $1 \mathrm{mmol}$ ) and $1 \mathrm{~mL}$ anhydrous toluene was added into a three-necked flask equipped with magnetic stirring and $\mathrm{N}_{2}$ protection. The polycondenzation was carried out at 120 ${ }^{\circ} \mathrm{C}$ in an oil bath when $\mathrm{Ti}(\mathrm{OiPr})_{4}(0.01 \mathrm{mmol}, 10 \mathrm{uL})$ was added with a injector as the catalyst. After $4 \mathrm{~h}$ prepolymerization, the mixture became viscous. The system was further subjected to condensation in a high vacuum $(0.01 \mathrm{mbar}$ of $\mathrm{Hg})$ at $120{ }^{\circ} \mathrm{C}$ for $12 \mathrm{~h}$, and solid product was gained at the end. The final polyester was purified by dissolving in DCM, filtered and precipitated in methanol. After separated by centrifuge, the polymer was collected as solid. The final product was washed by methanol for three times and dried well under vacuum.

For monomer $\mathbf{3 b}$, melt polycondenzation procedure was taken compared with 3a, a similar procedure above was used without adding anhydrous toluene to produce the polyesters. 


\section{$3.2{ }^{1} \mathrm{H}-\mathrm{NMR}$ spectra of chiral polyesters}

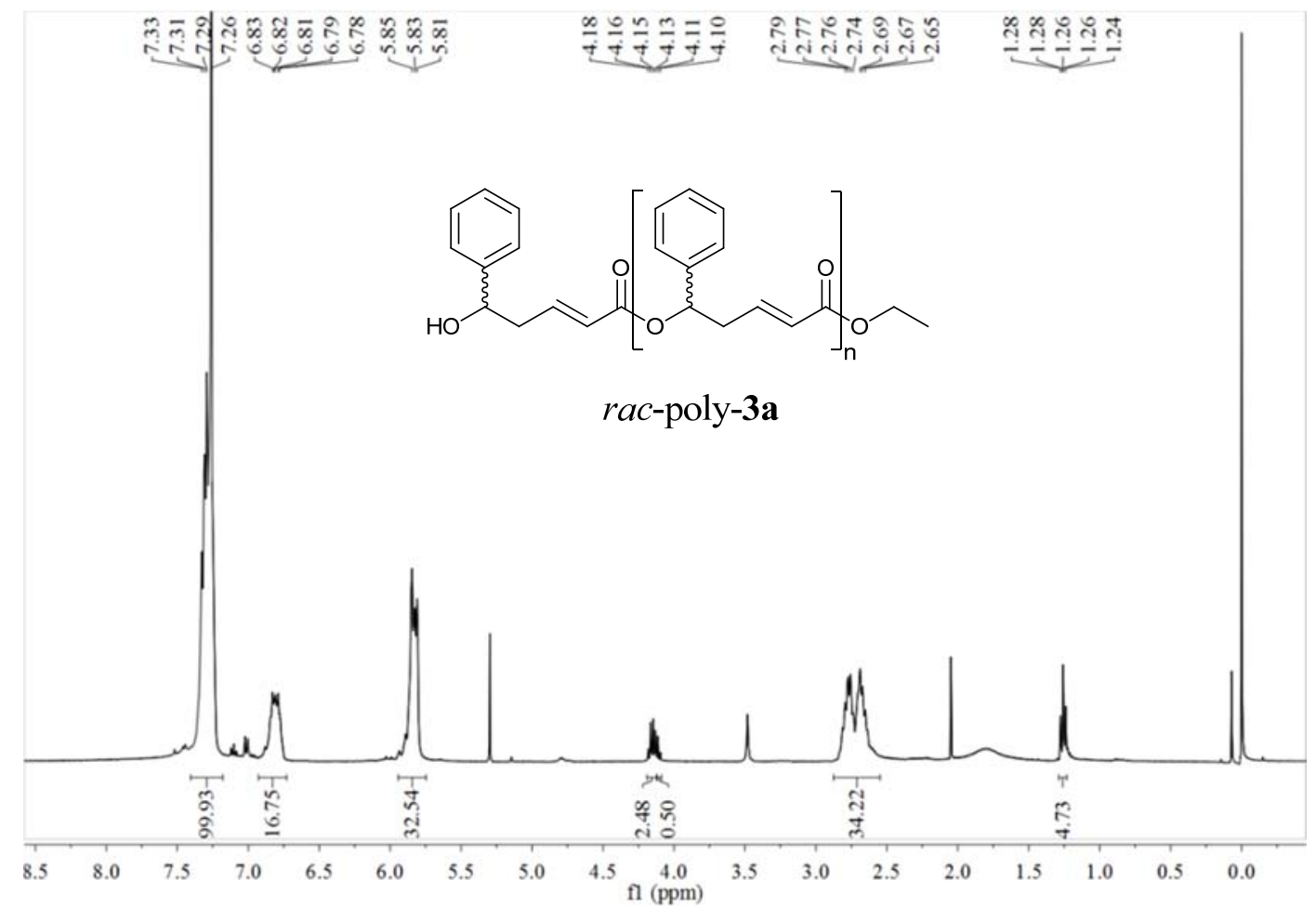

Figure S3. ${ }^{1} \mathrm{H}-\mathrm{NMR}$ spectra of $r a c$-poly-3a

rac-poly-3a: ${ }^{1} \mathrm{H}$ NMR $\left(400 \mathrm{MHz}, \mathrm{CDCl}_{3}, \mathrm{ppm}\right): \delta 7.41-7.18\left(\mathrm{~m}, 5 \mathrm{H},-\mathrm{C}_{6} \mathrm{H}_{5}\right.$ of the side chain), $6.93-6.73\left(\mathrm{~m}, 1 \mathrm{H},=\mathrm{CH}-\mathrm{CH}_{2}-\right.$ in the backbone $), 5.94-5.75(\mathrm{~m}, 2 \mathrm{H},-\mathrm{CH}-$ of chiral carbon in the backbone, and $=\underline{\mathrm{CH}}-\mathrm{C}=\mathrm{O}$ in the backbone), $4.14(\mathrm{dq}, J=14.2,7.1 \mathrm{~Hz}, 1 \mathrm{H},-\underline{\mathrm{CH}}-\mathrm{OH}$ and O- $\underline{\mathrm{CH}_{2}}-\mathrm{CH}_{3}$ of the end group), $2.87-2.55$ (m, $2 \mathrm{H},-\underline{\mathrm{CH}_{2}}-$ of the backbone), 1.26 ( $\mathrm{t}, J=7.1 \mathrm{~Hz}$, $\mathrm{O}-\mathrm{CH}_{2}-\underline{\mathrm{CH}} 3$ of the end group). 


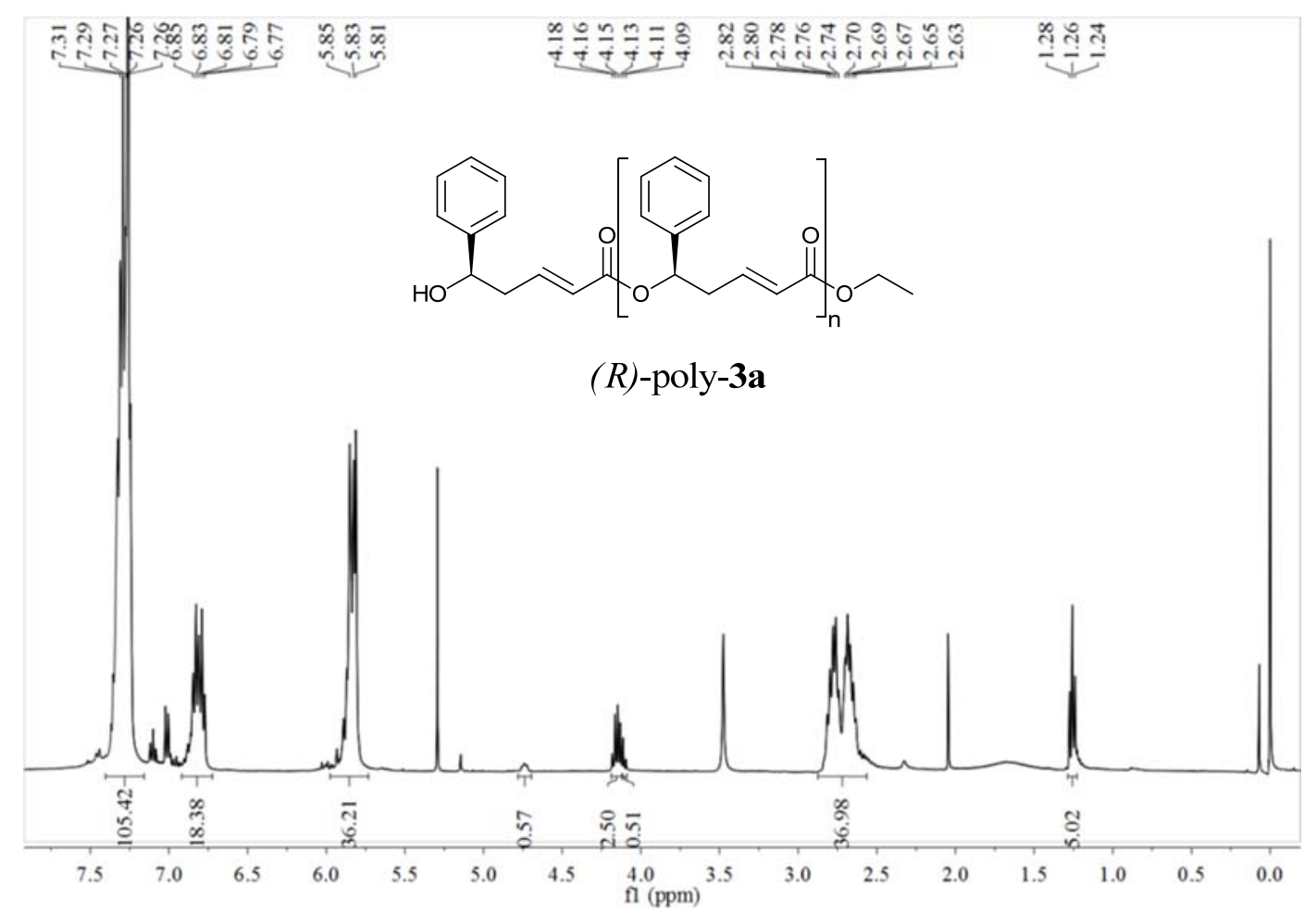

Figure S4. ${ }^{1} \mathrm{H}-\mathrm{NMR}$ spectra of $(R)$-poly-3a

(R)-poly-3a: ${ }^{1} \mathrm{H}$ NMR (400 MHz, $\left.\mathrm{CDCl}_{3}, \mathrm{ppm}\right): \delta 7.40-7.16\left(\mathrm{~m}, 5 \mathrm{H},-\mathrm{C}_{6} \mathrm{H}_{5}\right.$ of the side chain), $6.92-6.72\left(\mathrm{~m}, 1 \mathrm{H},=\underline{\mathrm{CH}}-\mathrm{CH}_{2}-\right.$ in the backbone), $5.97-5.73(\mathrm{~m}, 2 \mathrm{H},-\mathrm{CH}-$ of chiral carbon in the backbone, and $=\underline{\mathrm{CH}}-\mathrm{C}=\mathrm{O}$ in the backbone), $4.14(\mathrm{dq}, J=14.2,7.1 \mathrm{~Hz},-\underline{\mathrm{CH}}-\mathrm{OH}$ and $\mathrm{O}-\mathrm{CH}_{2}-\mathrm{CH}_{3}$ of the end group), 2.72 (ddt, $J=43.8,13.9,6.8 \mathrm{~Hz}, 2 \mathrm{H},-\underline{\mathrm{CH}}_{2}-$ of the backbone), $1.26\left(\mathrm{t}, J=7.1 \mathrm{~Hz}, \mathrm{O}-\mathrm{CH}_{2}-\underline{\mathrm{CH}_{3}}\right.$ of the end group). 


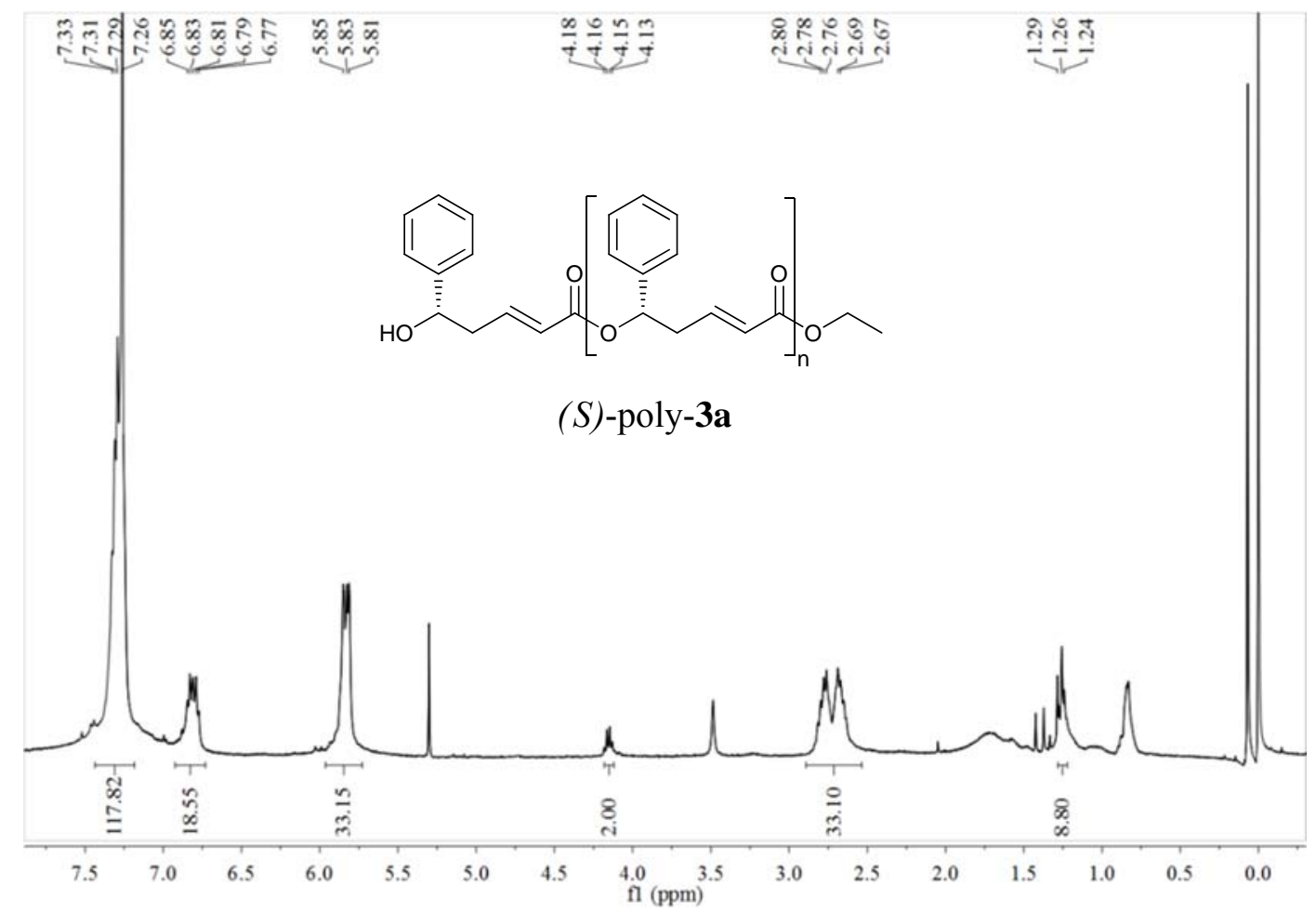

Figure S5. ${ }^{1} \mathrm{H}-\mathrm{NMR}$ spectra of $(S)$-poly-3a

(S)-poly-3a: ${ }^{1} \mathrm{H}$ NMR (400 MHz, $\left.\mathrm{CDCl}_{3}, \mathrm{ppm}\right): \delta 7.41-7.18\left(\mathrm{~m}, 5 \mathrm{H},-\mathrm{C}_{6} \mathrm{H}_{5}\right.$ of the side chain), $6.93-6.73\left(\mathrm{~m}, 1 \mathrm{H},=\underline{\mathrm{CH}}-\mathrm{CH}_{2}-\right.$ in the backbone), $5.94-5.75(\mathrm{~m}, 2 \mathrm{H},-\mathrm{CH}-$ of chiral carbon in the backbone, and $=\underline{\mathrm{CH}}-\mathrm{C}=\mathrm{O}$ in the backbone), $4.14(\mathrm{dq}, J=14.2,7.1 \mathrm{~Hz},-\underline{\mathrm{CH}}-\mathrm{OH}$ and $\mathrm{O}-\mathrm{CH}_{2}-\mathrm{CH}_{3}$ of the end group), $2.87-2.55\left(\mathrm{~m}, 2 \mathrm{H},-\underline{\mathrm{CH}}_{2}-\right.$ of the backbone), $1.26(\mathrm{t}, J=8.1 \mathrm{~Hz}$, $\mathrm{O}-\mathrm{CH}_{2}-\underline{\mathrm{CH}_{3}}$ of the end group). 


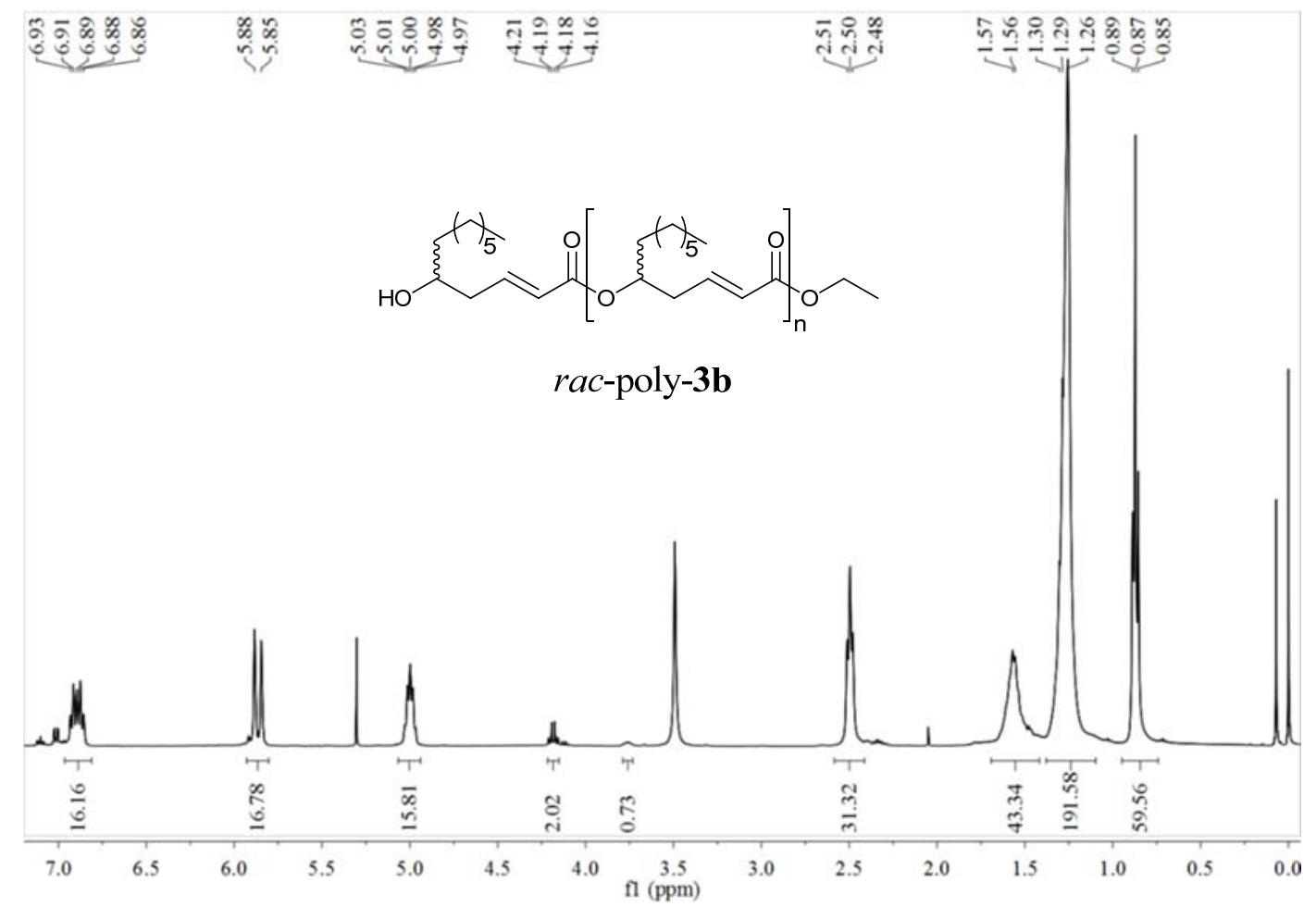

Figure S6. ${ }^{1} \mathrm{H}-\mathrm{NMR}$ spectra of $r a c$-poly-3b

rac-poly-3b: ${ }^{1} \mathrm{H}$ NMR $\left(400 \mathrm{MHz}, \mathrm{CDCl}_{3}, \mathrm{ppm}\right): \delta 6.96-6.81\left(\mathrm{~m}, 1 \mathrm{H},=\underline{\mathrm{CH}}-\mathrm{CH}_{2}-\right.$ in the backbone), $5.87(\mathrm{~d}, J=15.6 \mathrm{~Hz}, 1 \mathrm{H},=\underline{\mathrm{CH}}-\mathrm{C}=\mathrm{O}$ in the backbone), $5.07-4.94(\mathrm{~m}, 1 \mathrm{H},-\mathrm{CH}-\mathrm{of}$ chiral carbon in the backbone), $4.18\left(\mathrm{q}, J=7.1, \mathrm{O}-\mathrm{CH}_{2}-\mathrm{CH}_{3}\right.$ of the end group), 3.76 (m, - $\underline{\mathrm{CH}}-\mathrm{OH}$ of the end group), $2.50\left(\mathrm{t}, J=6.3 \mathrm{~Hz}, 2 \mathrm{H},-\underline{\mathrm{CH}}_{2}-\right.$ in the backbone), $1.56-1.57(\mathrm{~m}, 2 \mathrm{H}$, $\mathrm{CH}-\underline{\mathrm{CH}}_{2}$ of side chain), $1.38-1.10\left(\mathrm{~m}, 10 \mathrm{H},-{\underline{\left(\mathrm{CH}_{2}\right.}}_{2} 5^{-}\right.$of side chain), $0.87(\mathrm{t}, J=6.8 \mathrm{~Hz}, 3 \mathrm{H}$, $-\mathrm{CH}_{3}$ of side chain). 


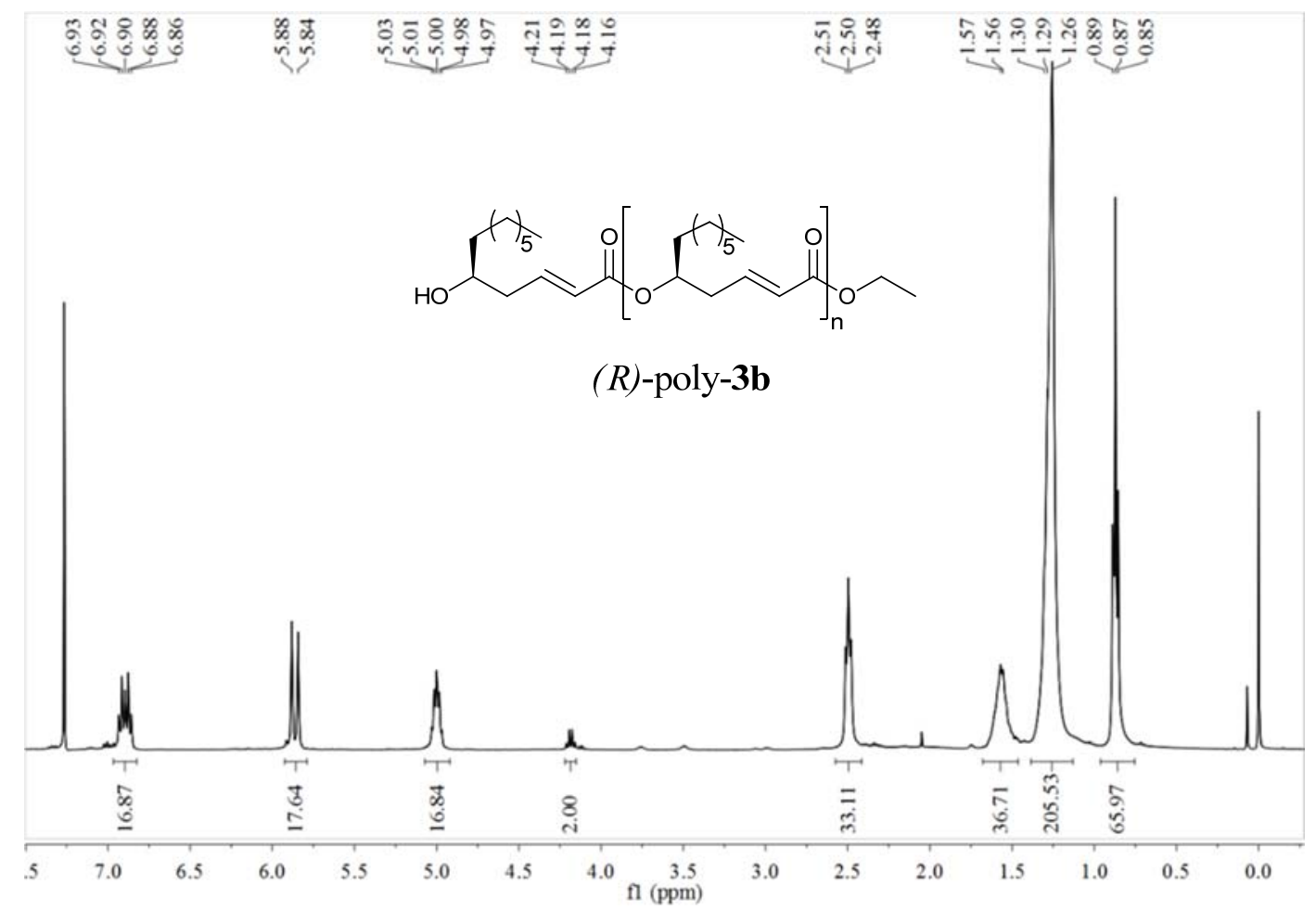

Figure S7. ${ }^{1} \mathrm{H}-\mathrm{NMR}$ spectra of $(R)$-poly-3b

(R)-poly-3b: ${ }^{1} \mathrm{H}$ NMR $\left(400 \mathrm{MHz}, \mathrm{CDCl}_{3}, \mathrm{ppm}\right): \delta 6.97-6.82\left(\mathrm{~m}, 1 \mathrm{H},=\underline{\mathrm{CH}}-\mathrm{CH}_{2}-\right.$ in the backbone), $5.86(\mathrm{~d}, J=15.6 \mathrm{~Hz}, 1 \mathrm{H},=\underline{\mathrm{CH}}-\mathrm{C}=\mathrm{O}$ in the backbone $), 5.07-4.92(\mathrm{~m}, 1 \mathrm{H},-\mathrm{CH}-\mathrm{of}$ chiral carbon in the backbone), $4.18\left(\mathrm{q}, J=7.1 \mathrm{~Hz}, \mathrm{O}-\underline{\mathrm{CH}}_{2}-\mathrm{CH}_{3}\right.$ of the end group), 3.76 (m, - $\underline{\mathrm{CH}}-\mathrm{OH}$ of the end group), $2.50\left(\mathrm{t}, J=6.2 \mathrm{~Hz}, 2 \mathrm{H},-\underline{\mathrm{CH}}_{2}-\right.$ in the backbone), $1.56-1.57(\mathrm{~m}, 2 \mathrm{H}$, $\mathrm{CH}-\underline{\mathrm{CH}}_{2}$ of side chain), 1.26-1.30 (m, $10 \mathrm{H},-\underline{\left(\mathrm{CH}_{2}\right)_{5}-}$ of side chain), 0.85-0.89 (t, $J=6.7 \mathrm{~Hz}$, $3 \mathrm{H},-\mathrm{CH}_{3}$ of side chain). 


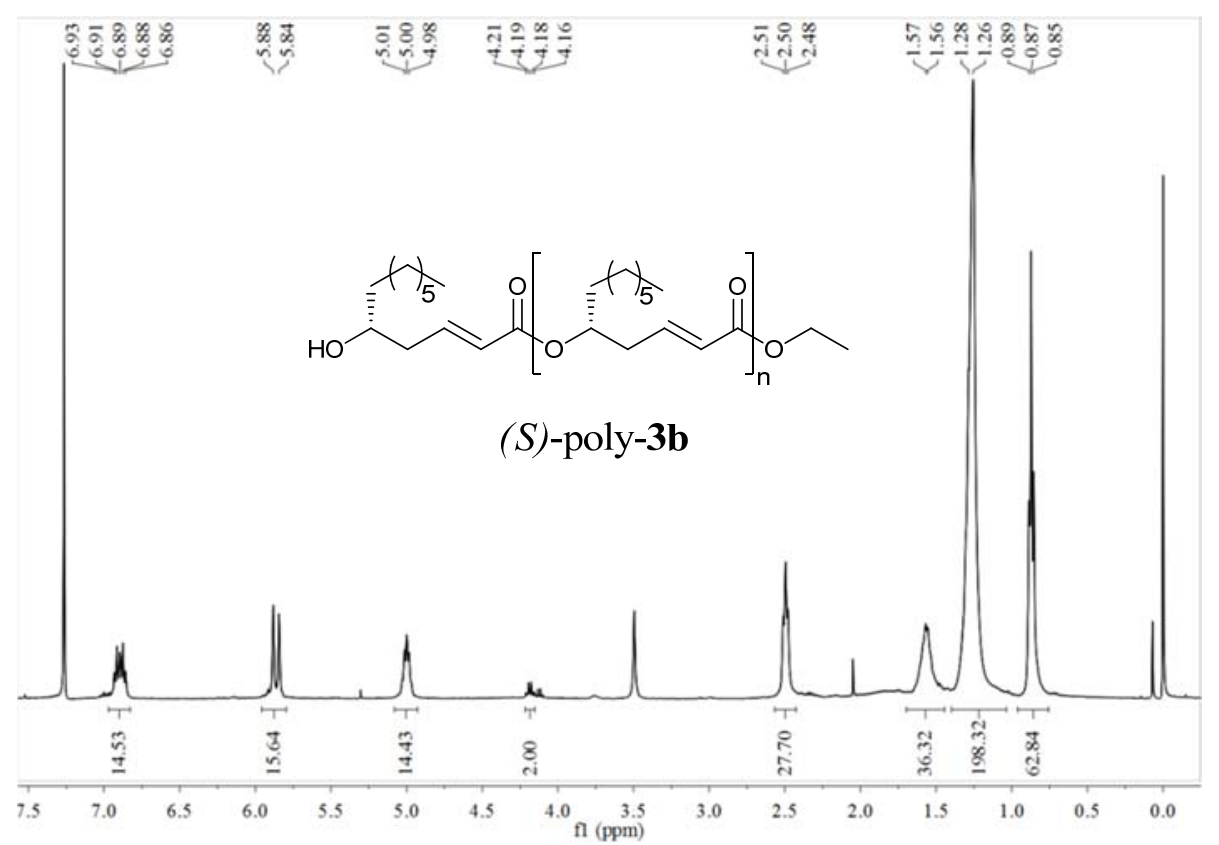

Figure S8. ${ }^{1} \mathrm{H}-\mathrm{NMR}$ spectra of (S)-poly-3b

(S)-poly-3b: ${ }^{1} \mathrm{H}$ NMR $\left(400 \mathrm{MHz}, \mathrm{CDCl}_{3}, \mathrm{ppm}\right): \delta 6.97-6.83\left(\mathrm{~m}, 1 \mathrm{H},=\underline{\mathrm{CH}}-\mathrm{CH}_{2}\right.$ - in the backbone), $5.86(\mathrm{~d}, J=15.6 \mathrm{~Hz}, 1 \mathrm{H},=\underline{\mathrm{CH}}-\mathrm{C}=\mathrm{O}$ in the backbone), $5.08-4.93(\mathrm{~m}, 1 \mathrm{H},-\mathrm{CH}-$ of chiral carbon in the backbone), 4.18 (q, $J=7.1 \mathrm{~Hz}, \mathrm{O}-\mathrm{CH}_{2}-\mathrm{CH}_{3}$ of the end group), 3.72-3.76 (m, $-\underline{\mathrm{CH}}-\mathrm{OH}$ of the end group), $2.50\left(\mathrm{t}, J=6.2 \mathrm{~Hz}, 2 \mathrm{H},-\underline{\mathrm{CH}}_{2}-\right.$ in the backbone), 1.56-1.57 (m, $2 \mathrm{H}, \mathrm{CH}-\underline{\mathrm{CH}}_{2}$ of side chain), 1.26-1.30 (m, $10 \mathrm{H},-\left(\mathrm{CH}_{2} 2_{2}-\right.$ of side chain), 0.87 (t, $J=6.6 \mathrm{~Hz}$, $3 \mathrm{H},-\mathrm{CH}_{3}$ of side chain). 


\subsection{GPC data of chiral polyesters}

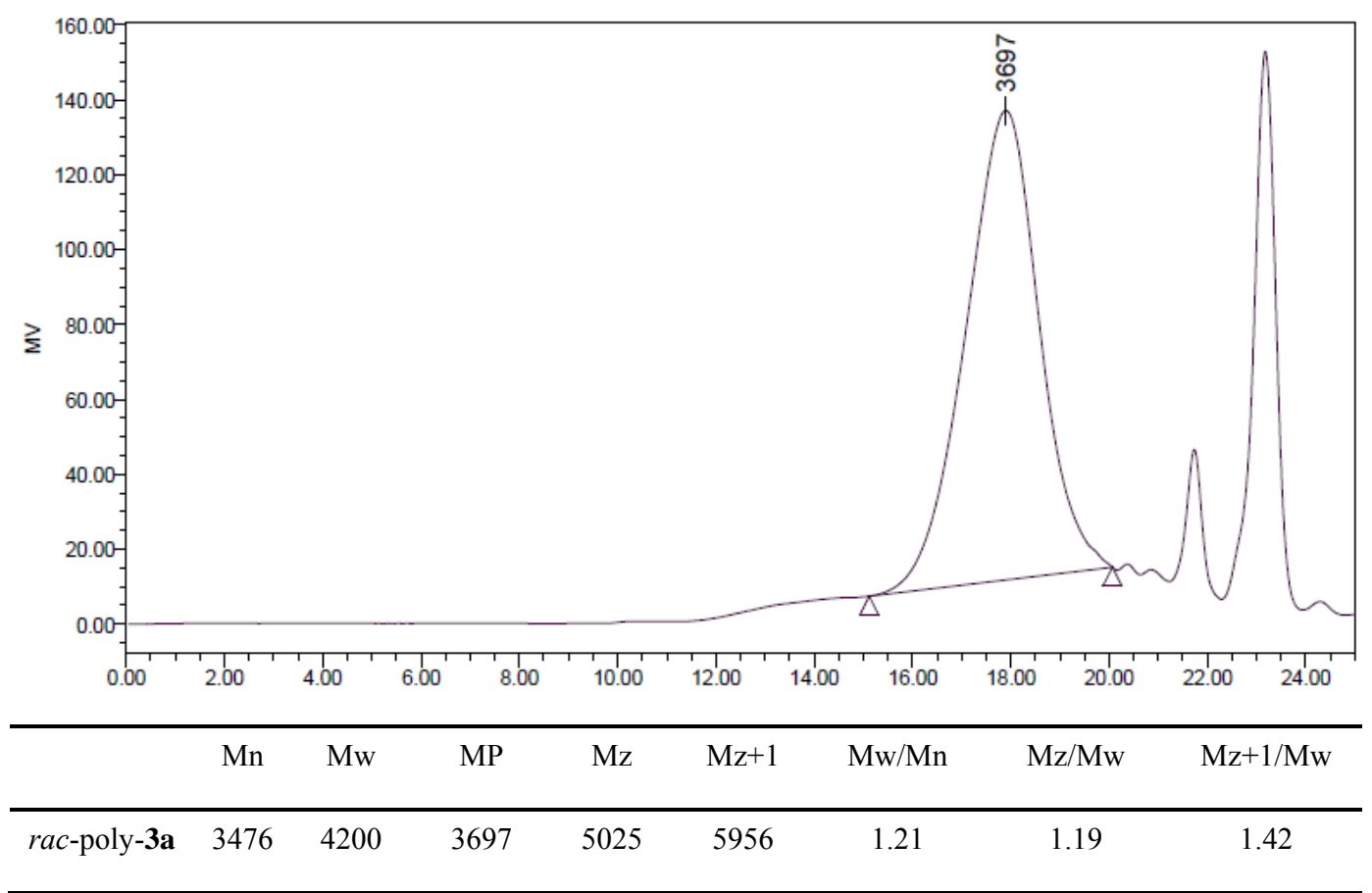

Figure S9. GPC data of rac-poly-3a

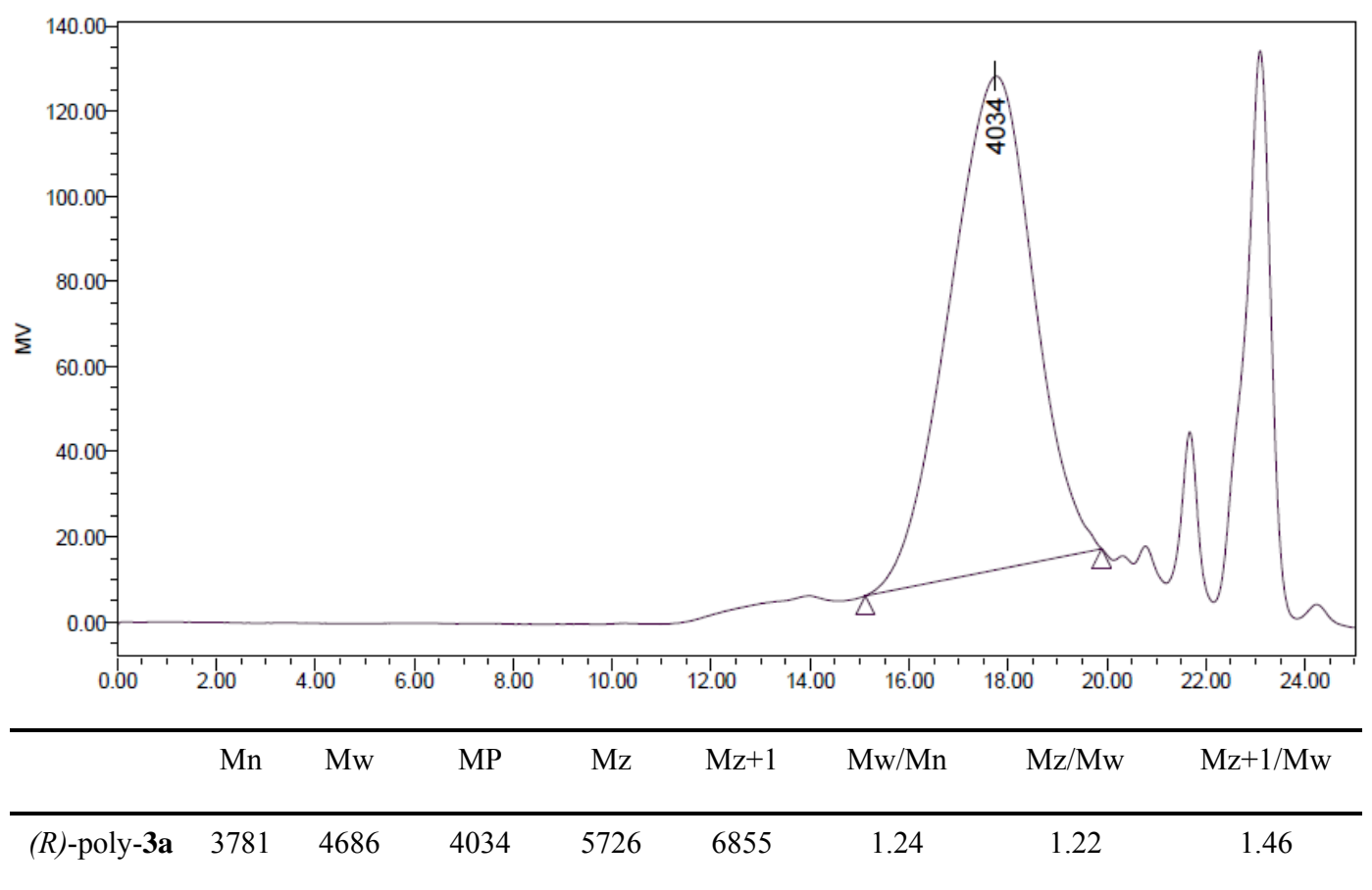

Figure S10. GPC data of (R)-poly-3a 


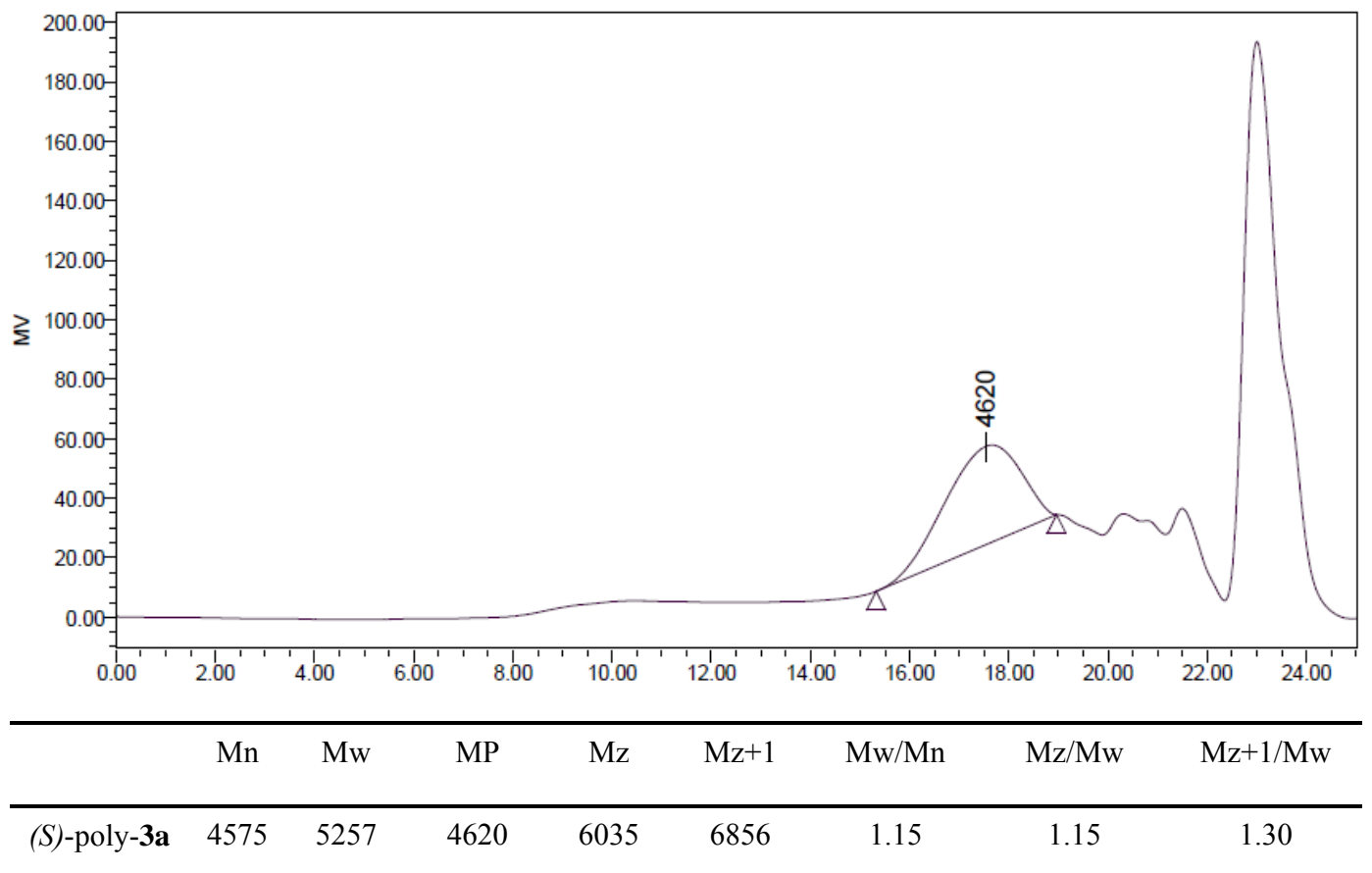

Figure S11. GPC data of (S)-poly-3a

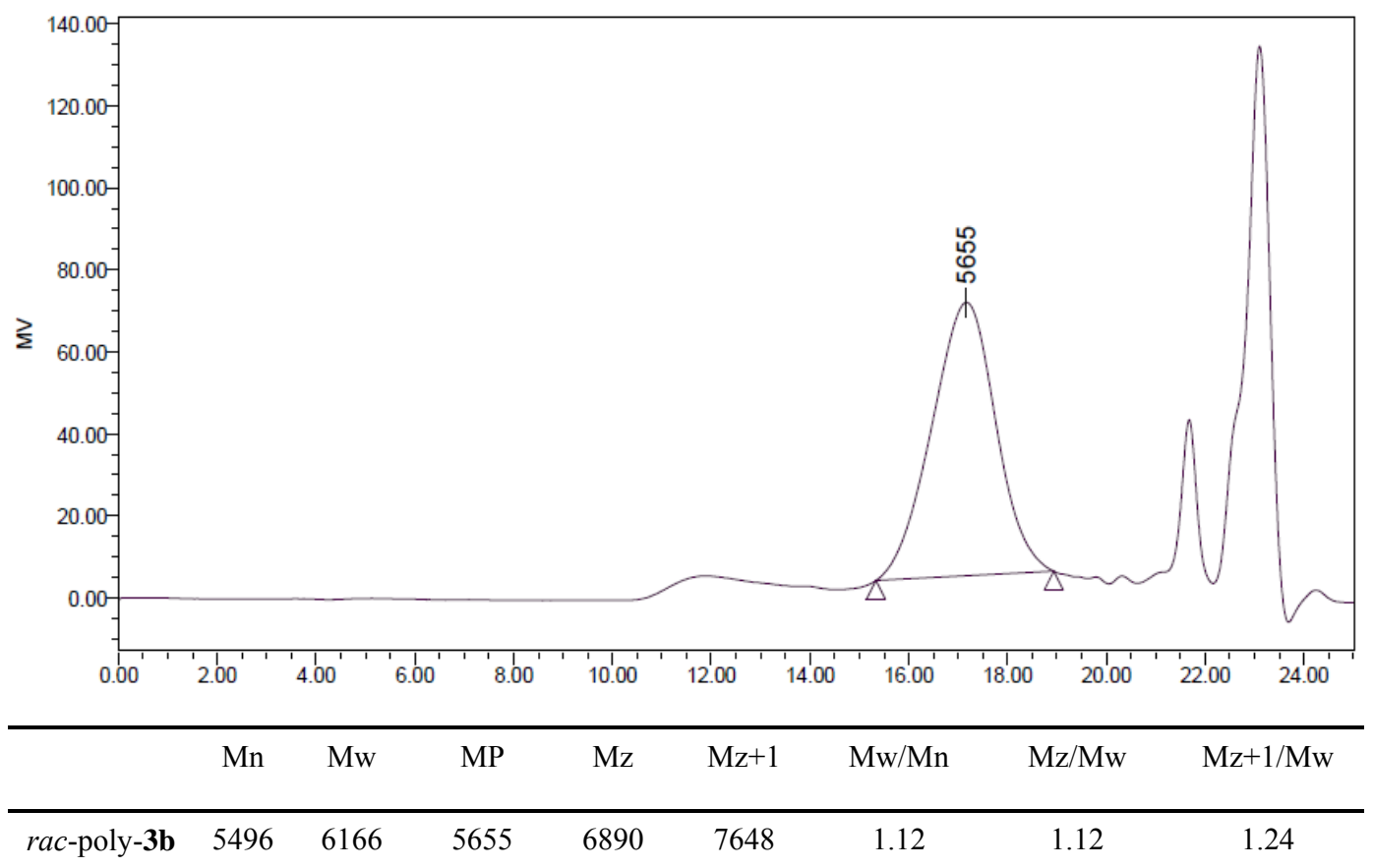

Figure S12. GPC data of $r a c$-poly-3b 


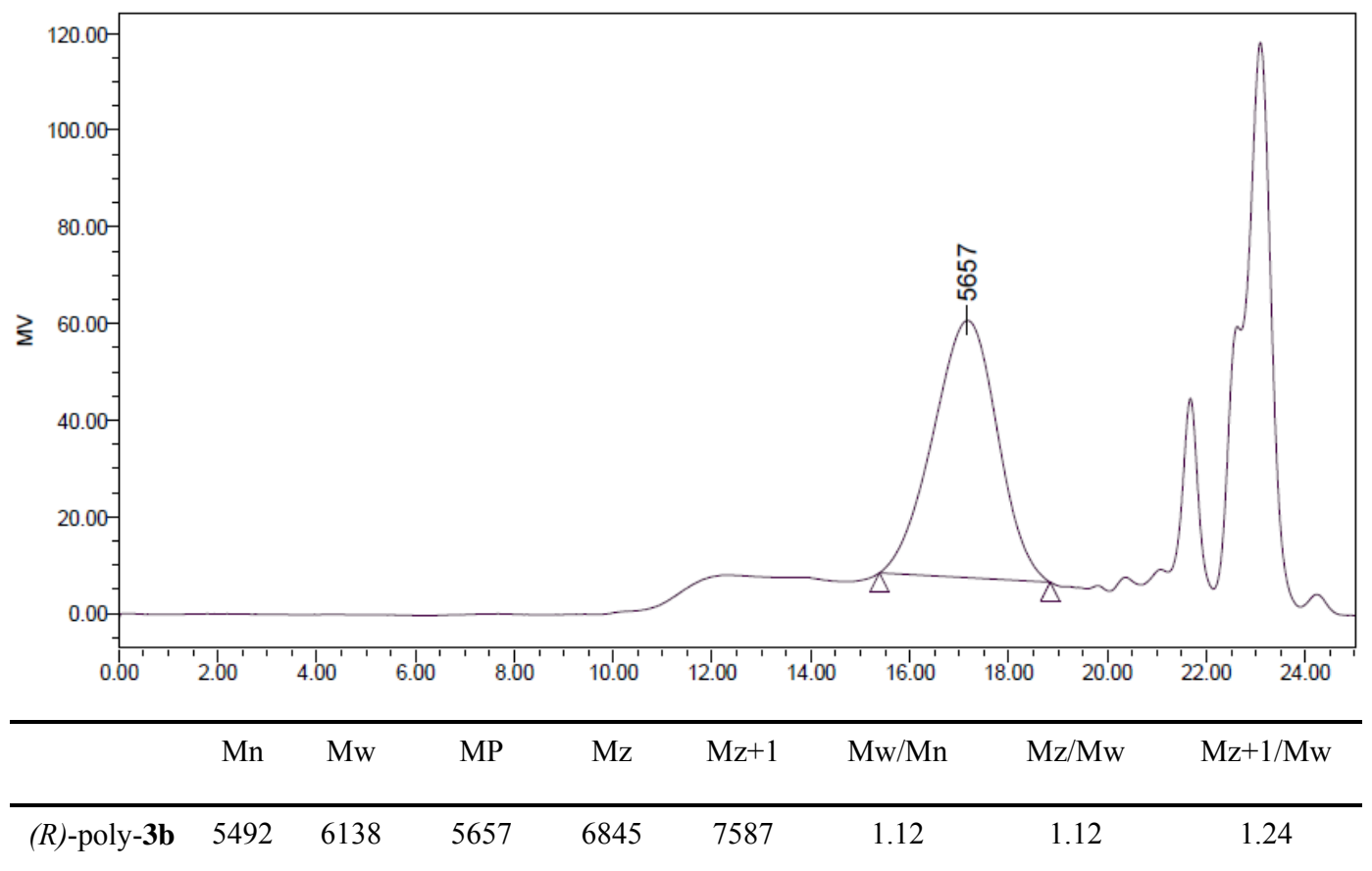

Figure S13. GPC data of (R)-poly-3b

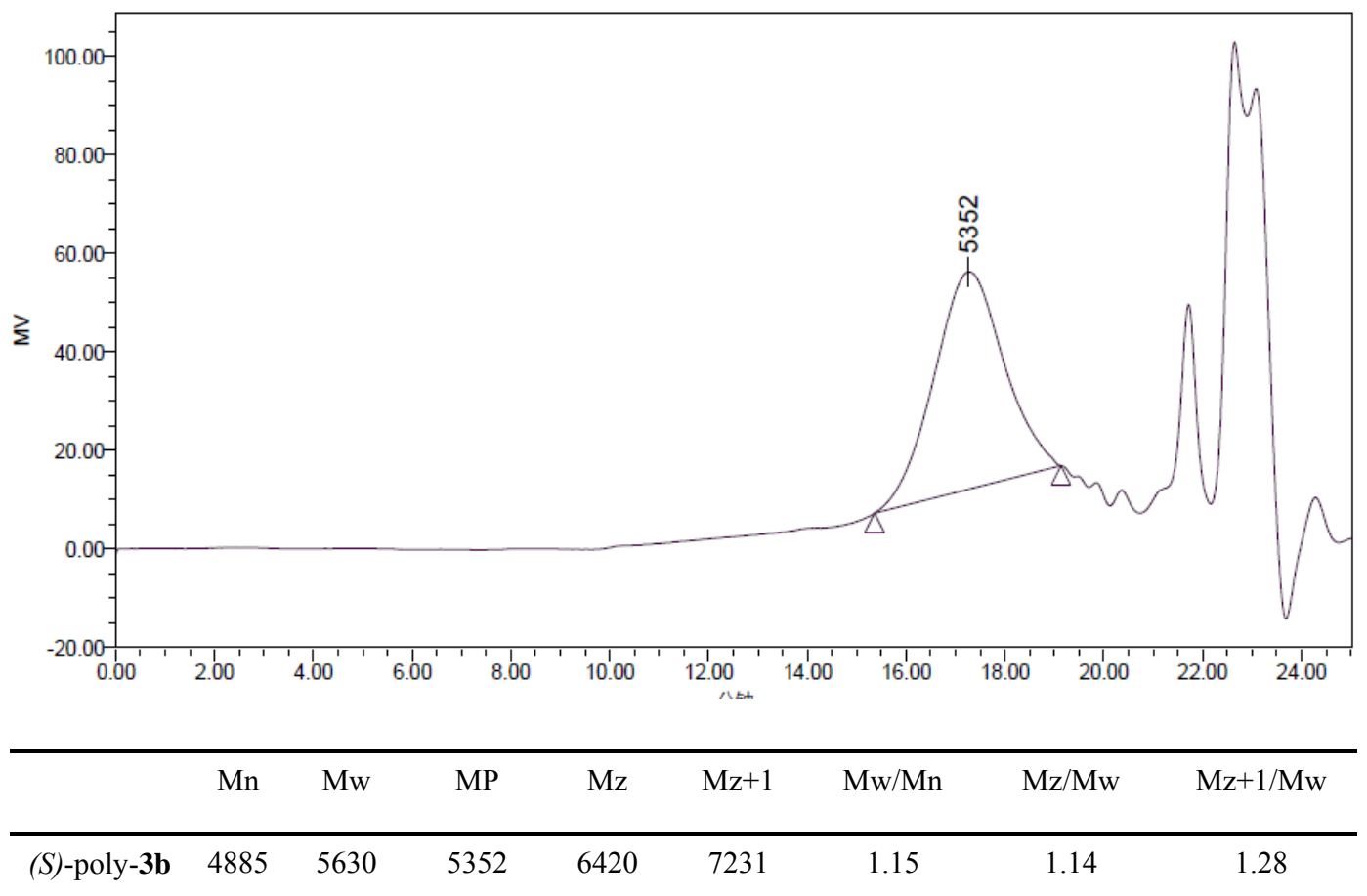

Figure S14. GPC data of (S)-poly-3b 


\section{Supplementary figures}

\subsection{Morphology characterization by SEM}
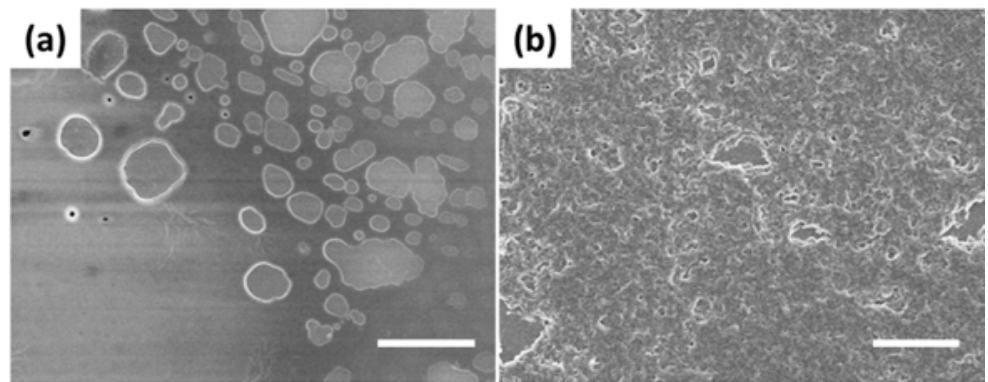

Figure S15. SEM images of $(S)$-poly-3b, (a) the sample was solved in DCM, then dried under vacuum; (b) the sample was precipitated in hexane (Scale bar, $5 \mathrm{um}$ ).
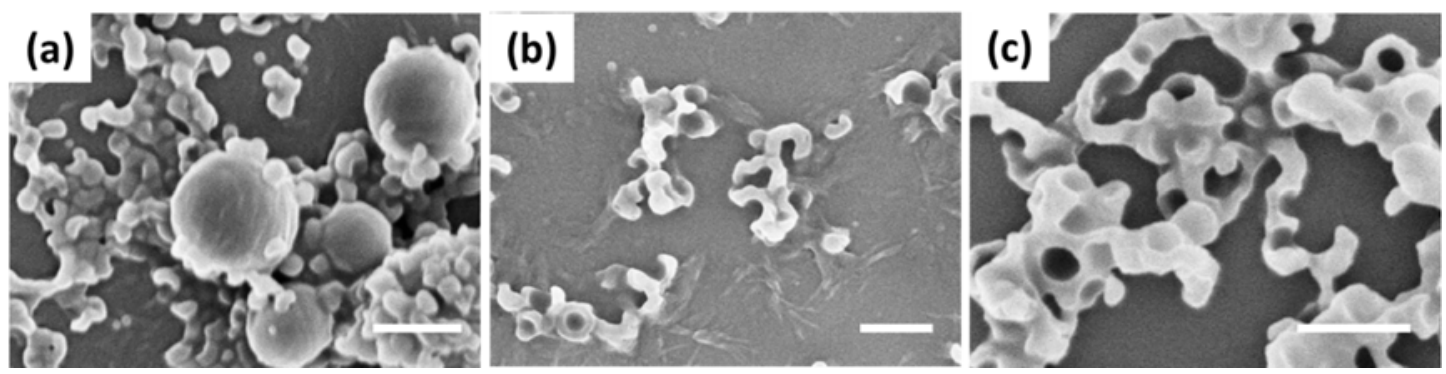

Figure S16. SEM images of $(S)$-poly-3a, solved in $0.1 \mathrm{~mL} \mathrm{DCM}$ at $0.5 \mathrm{mg} / \mathrm{mL}$, and (a) $0.4 \mathrm{~mL}$ methanol, (b) $0.2 \mathrm{~mL}$ methanol, (c) $0.1 \mathrm{~mL}$ methanol was added (Scale bar, $500 \mathrm{~nm}$ ).
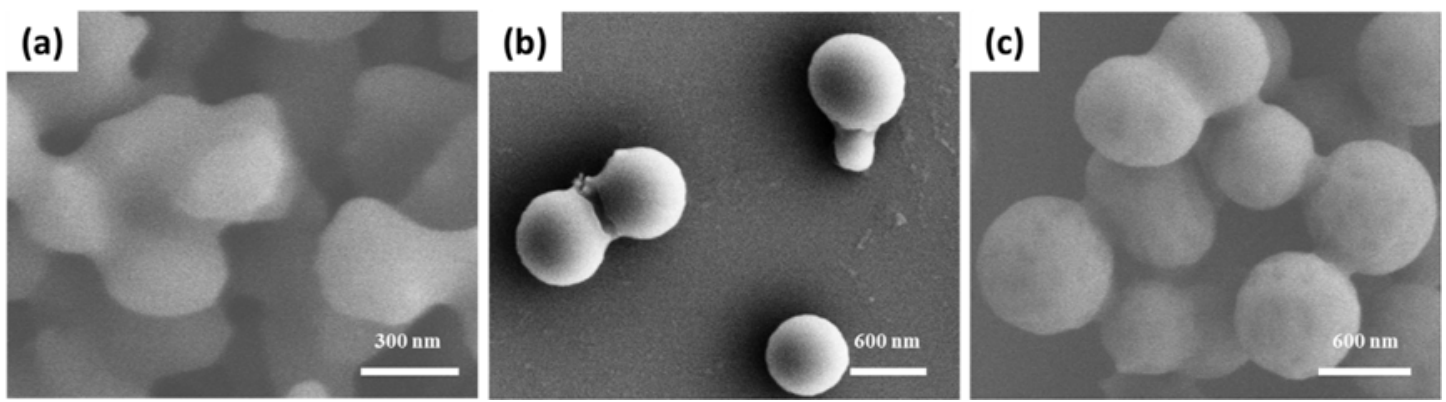

Figure S17. SEM images of the self-assembled nanostructure of $(S)$-poly-3a, precipitated from the DCM solutions $(0.1 \mathrm{~mL})$ with different concentrations (a) $0.2 \mathrm{mg} / \mathrm{mL}$, (b) $0.5 \mathrm{mg} / \mathrm{mL}$ and (c) 1 $\mathrm{mg} / \mathrm{mL}$, after the addition of $1 \mathrm{~mL}$ hexane. They are the enlarged images of Figure 1. 

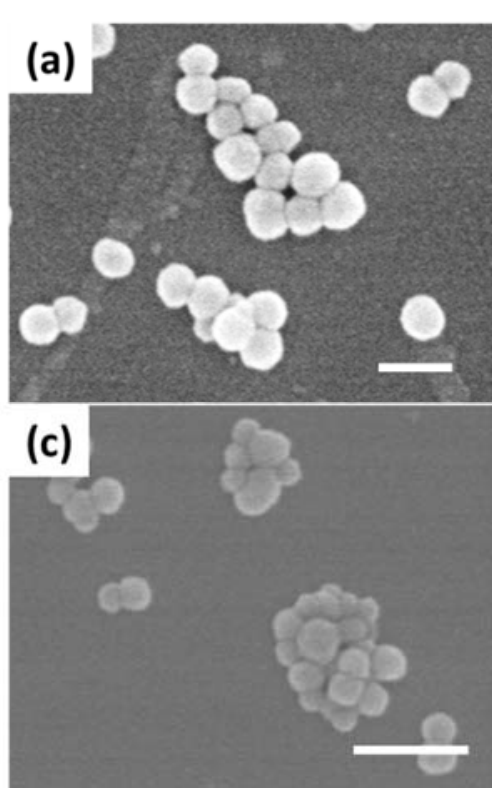

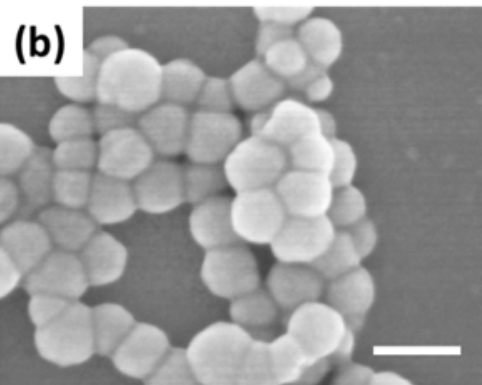

(d)

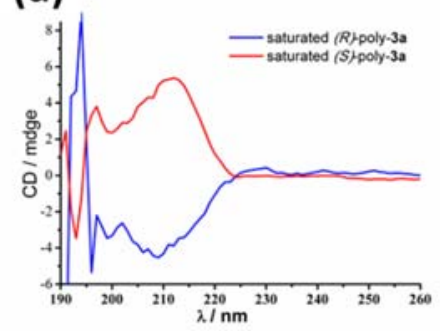

Figure S18. SEM images of (a) saturated rac-poly-3a, (b) saturated ( $R$ )-poly-3a, (b) saturated (S)-poly-3a. Sample preparation procedure: saturated polyesters were solved in $0.1 \mathrm{~mL} \mathrm{DCM}$ at $0.5 \mathrm{mg} / \mathrm{mL}$, and $0.1 \mathrm{~mL}$ hexane was added (Scale bar, $100 \mathrm{~nm}$ ). (d) CD spectra of saturated $(R)$ -poly-3a and $(S)$-poly-3a in acetonitrile with concentration of $1 \times 10^{-5} \mathrm{~mol} / \mathrm{L}$.

\subsection{XRD analysis of polyesters}

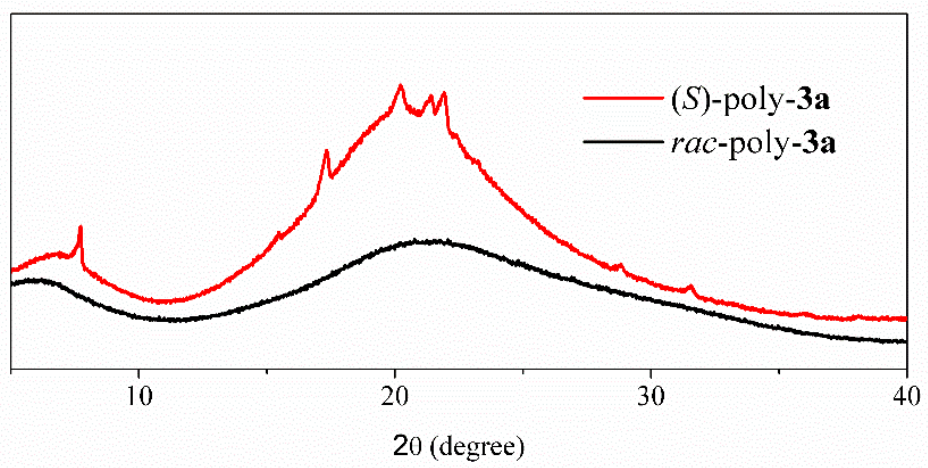

Figure S19. XRD profiles of rac-poly-3a, and $(S)$-poly-3a. 


\subsection{Thermal analysis of polyesters}
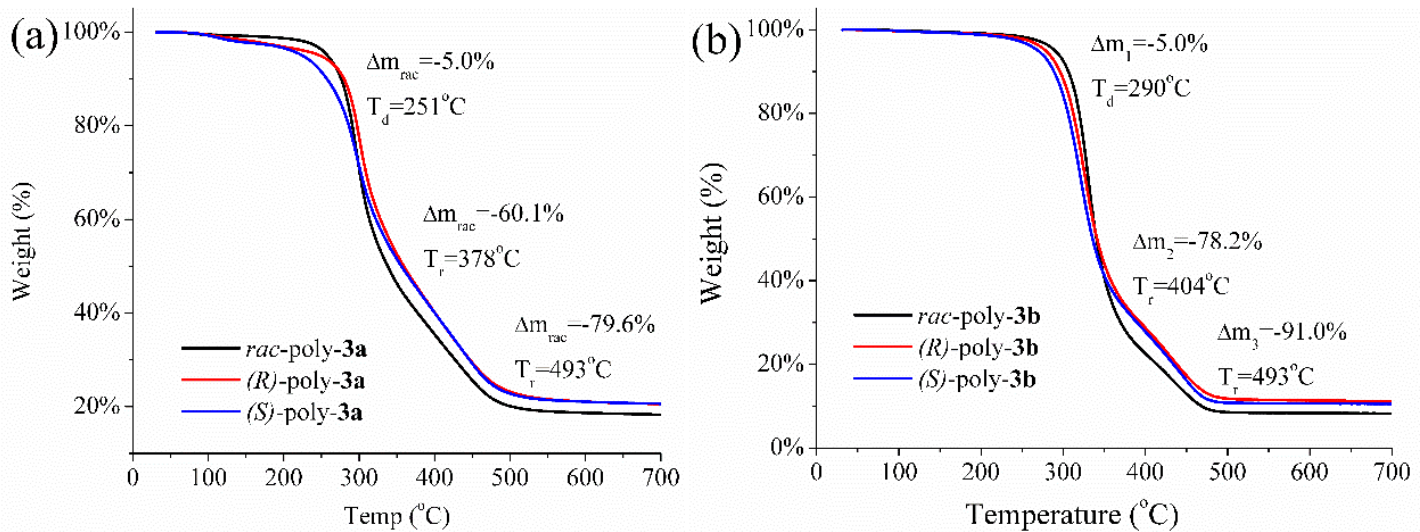

Figure S20. (a) TGA traces of poly-3a; (b) TGA traces of poly-3b, weight (\%) as a function of temperature $\left({ }^{\circ} \mathrm{C}\right)$.
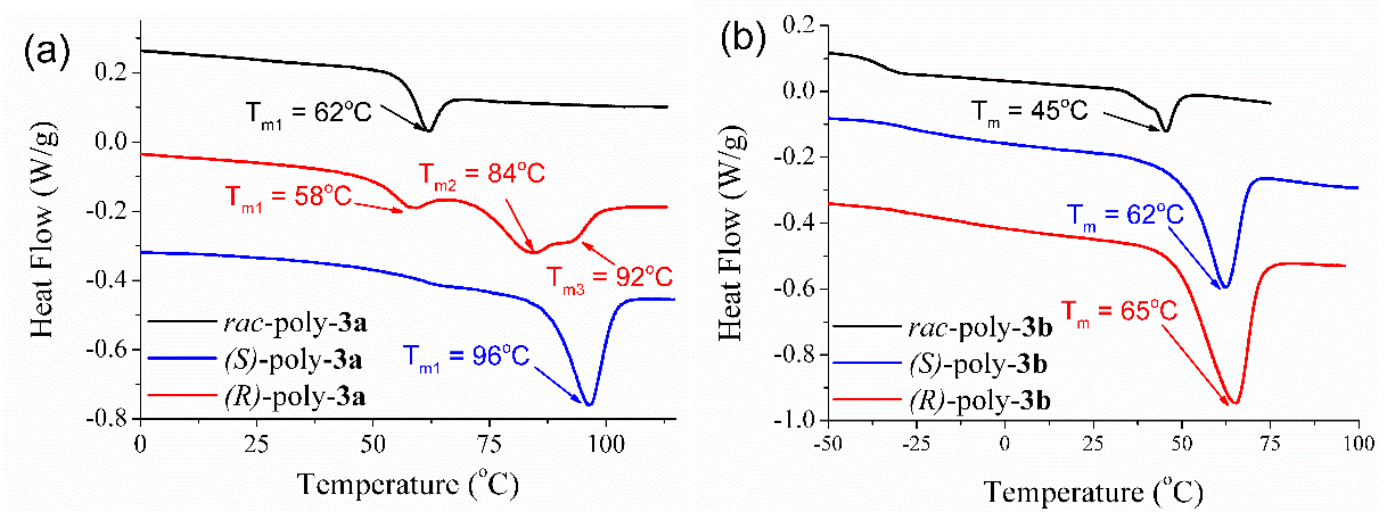

Figure S21. (a) DSC curve of $r a c-,(R)$ - and (S)-poly-3a; (b) DSC curve of rac-, $(R)$ - and (S)-poly-3b.

\subsection{CD analysis of polyesters}

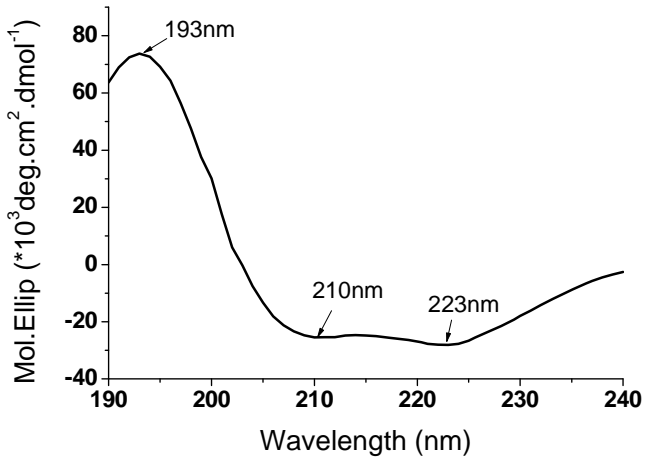

Figure S22. CD spectra molar ellipticity curve of $(S)$-poly-3b. 


\section{Reference}

(1) Cen, Y. X.; Li, D. Y.; Xu, J.; Wu, Q. S.; Wu, Q.; Lin, X. F. Highly Focused Library-Based Engineering of Candida Antarctica Lipase B with (S)-Selectivity Towards sec-Alcohols. Adv. Synth. Catal. 2019, 361, 126-134.

(2) Xia, B.; Xu, J.; Xiang, Z. W.; Cen, Y.X.; Hu, Y.J.; Lin, X. F.; Wu, Q. Stereoselectivity-Tailored, Metal-Free Hydrolytic Dynamic Kinetic Resolution of Morita-Baylis-Hillman Acetates Using an Engineered Lipase-Organic Base Cocatalyst. ACS Catal. 2017, 7, 4542-4549.

(3) Warner, M. C.; Shevchenko, G. A.; Jouda, S.; Bogár, K.; Bäckvall, J. E. Dynamic Kinetic Resolution of Homoallylic Alcohols: Application to The Synthesis of Enantiomerically Pure 5,6-dihydropyran-2-ones and $\delta$-Lactones. Chem. Eur. J., 2013, 19, 13859 - 13864.

(4) Sumida, S. I.; Ohga, M.; Mitani, J.; Nokami, J. New and Stereoselective Synthesis of 1,4-disubstituted buten-4-ols (Homoallylic Alcohol a-Adducts) from the Corresponding $\gamma$-Isomers (3,4-disubstituted buten-4-ols) via an Acid-Catalyzed Allyl-Transfer Reaction with Aldehydes. J. Am. Chem. Soc. 2000, 122(7), 1310-1313.

(5) Chandrasekhar, S.; Balaji, S. V.; Rajesh, G. First total Synthesis of Achaetolide. Tetrahedron Letters 2010, 51, 5164-5166. 